\title{
Understanding the Role of EGFR in the Treatment of Head and Neck Squamous Cell Carcinoma
}

\author{
Adam Jedliński
}

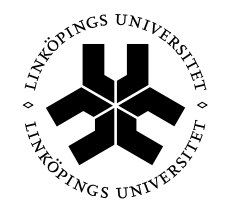

Linköping University

FACULTY OF HEALTH SCIENCES

Department of Otorhinolaryngology Department of Clinical and Experimental Medicine Faculty of Health Sciences, Linköping University SE-581-83 Linköping, Sweden 
(C) Adam Jedlinski 2015

Cover picture images taken in Chuuk by Joakim Jarsmo

Published articles have been reprinted with the permission of the copyright holders.

Printed in Sweden by LiU-Tryck, Linköping, Sweden, 2015

ISBN: 978-91-7519-176-8

ISSN: 0345-0082 
To my treasured Family

"Better to remain silent and be thought a fool than to speak and remove all doubt." 


\section{SUPERVISOR}

Karin Roberg, Professor

Division of Otorhinolaryngology and Head \& Neck Surgery

Department of Clinical and Experimental Medicine

Faculty of Health Sciences

Linköping University, Linköping, Sweden

CO-SUPERVISOR

Ann-Charlotte Johansson, $\mathrm{PhD}$

Division of Clinical Neurophysiology

Department of Clinical and Experimental Medicine

Faculty of Health Sciences

Linköping University, Linköping, Sweden

\section{OPPONENT}

Lars Ekblad, Associate Professor

Department of Oncology

Lund University, Lund, Sweden

\section{EXAMINATION COMMITTEE}

Xiao-Feng Sun, Professor

Division of Oncology

Department of Clinical and Experimental Medicine

Faculty of Health Sciences

Linköping University, Linköping, Sweden

Marika Nestor, Associate Professor

Department of Surgical Sciences

Otolaryngology and Head \& Neck Surgery

Akademiska Sjukhuset, Uppsala, Sweden

Oliver Gimm, Professor

Department of Clinical and Experimental Medicine

Faculty of Health Sciences

Linköping University, Linköping, Sweden 


\section{CONTENTS}

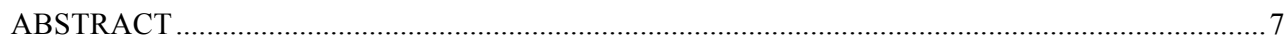

POPULÄRVETENSKAPLIG SAMMANFATTNING.................................................................... 9

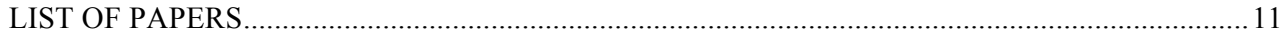

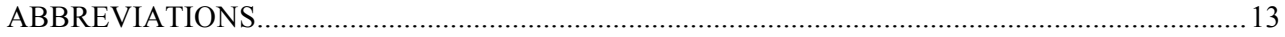

INTRODUCTION

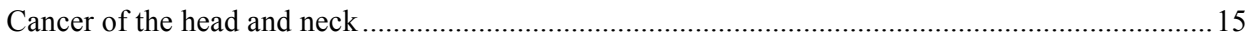

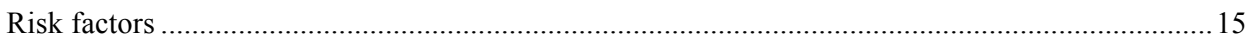

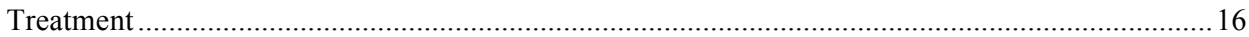

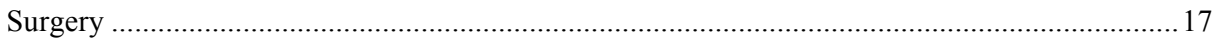

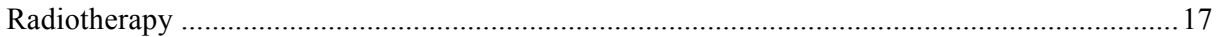

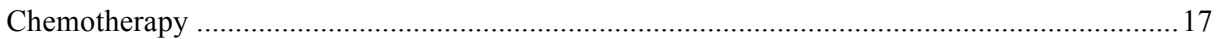

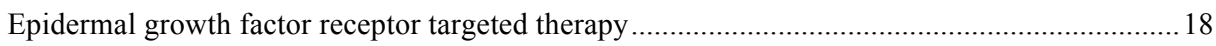

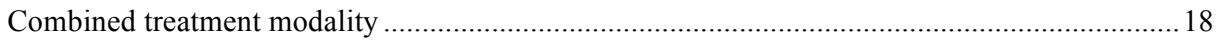

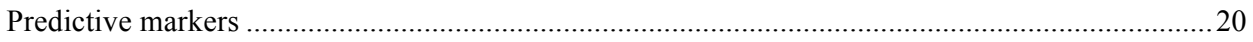

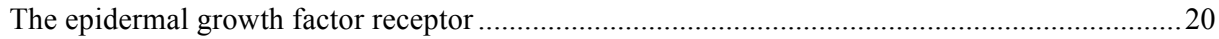

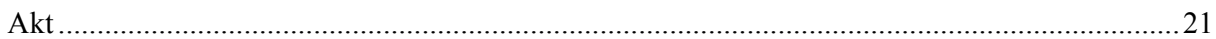

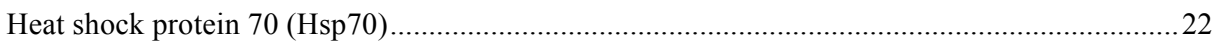

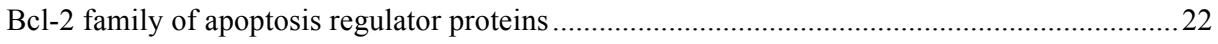

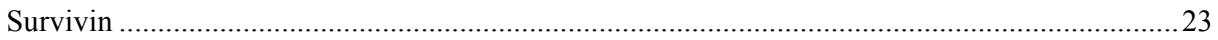

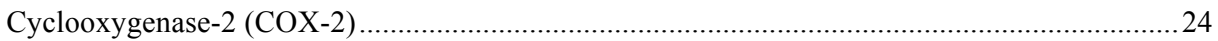

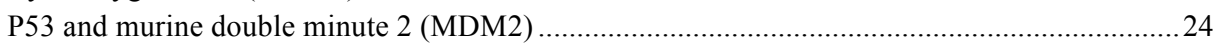

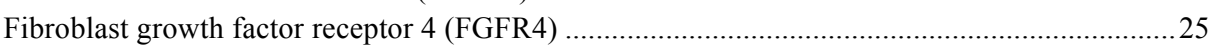

Single nucleotide polymorphisms in the DNA repair genes XPC, XPD, XRCC1, and XRCC3 .. 26

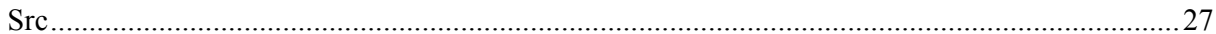

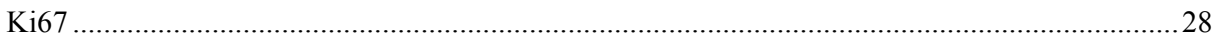

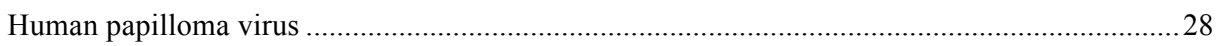

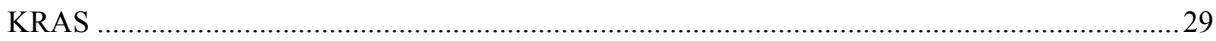

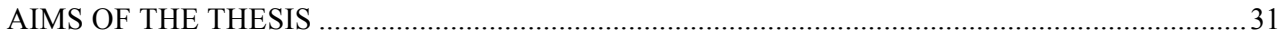

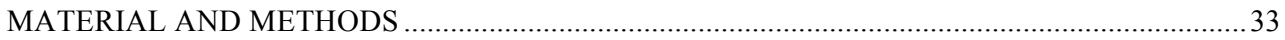

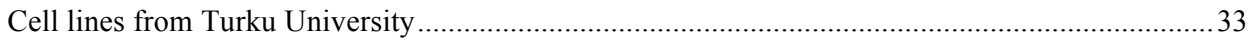

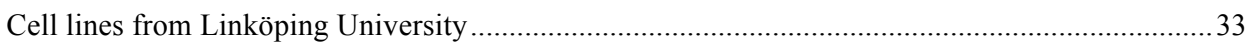

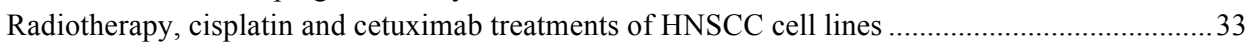

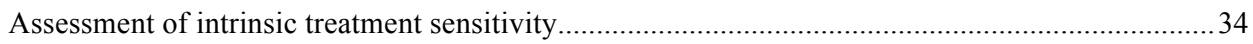

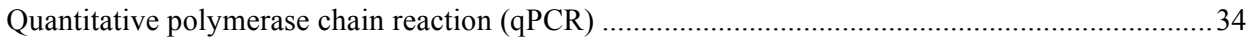

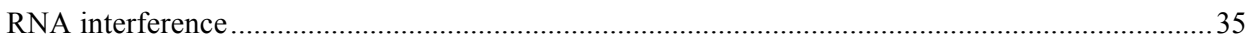

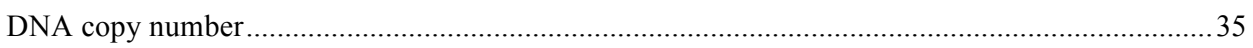

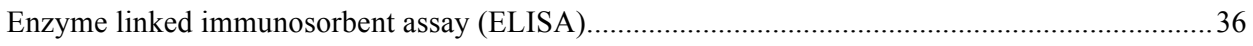

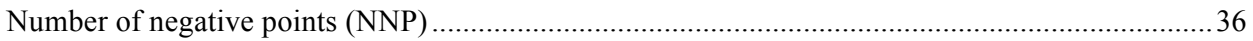

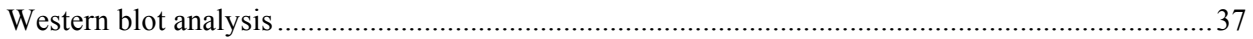

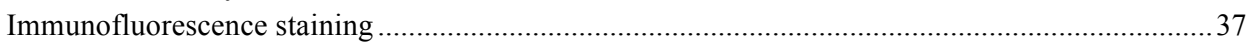

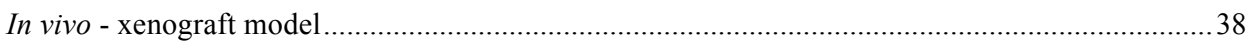

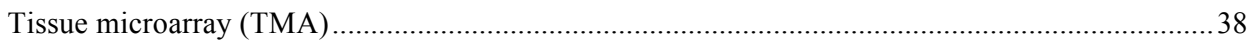

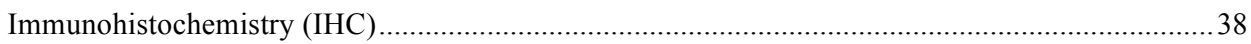




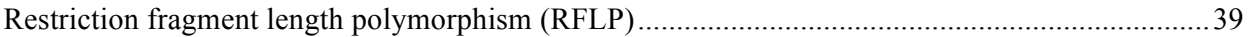

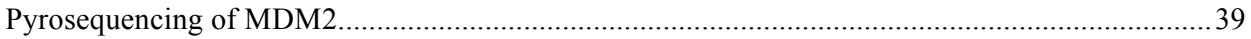

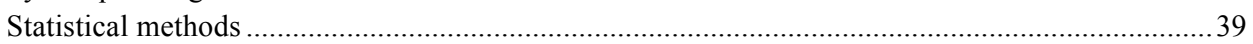

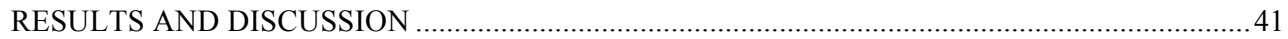

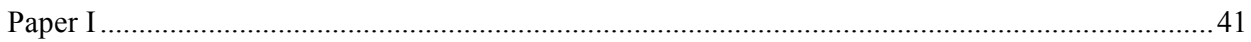

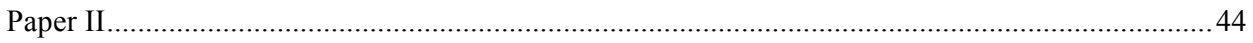

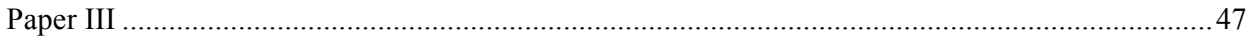

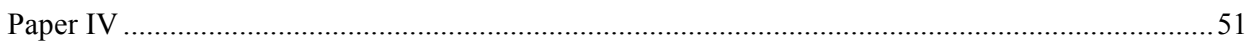

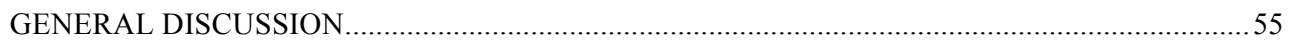

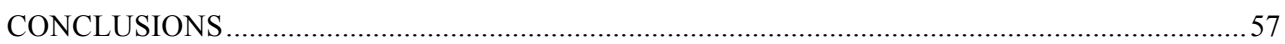

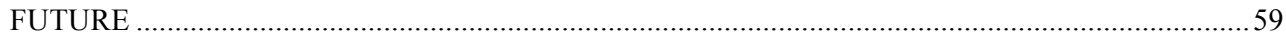

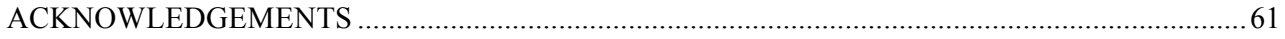

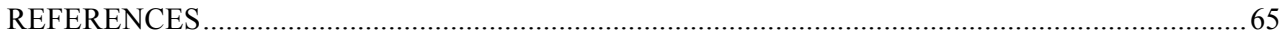




\section{ABSTRACT}

Head and neck squamous cell carcinoma (HNSCC) originates from the epithelial lining of the upper aerodigestive tract. It accounts for over $90 \%$ of the malignancies found in the head and neck region. 600,000 new cases of HNSCC occur each year worldwide. Apart from causing painful lesions, HNSCC directly impacts the patient's fundamental functions such as breathing and eating and also can disrupt the patient's senses such as smell, taste, speech and even vision. Most cases of HNSCC require a combination of different treatments such as surgery, chemotherapy (primarily cisplatin based), and radiotherapy. Treatment decisions are largely based on the size of the tumor, the involvement of local lymph nodes, and distant spread. Treatment resistance and local recurrence are significant problems and to date no form of clinical treatment sensitivity prediction is available.

A majority of HNSCC tumors overexpresses the epidermal growth factor receptor (EGFR). This receptor is involved in proliferation and DNA repair and is the target of a monoclonal antibody named cetuximab that selectively binds and inhibits EGFR. It is the only targeted therapy available to HNSCC patients and reserved for late stage patients in Sweden.

Numerous investigators have searched for predictive markers and we hypothesized that since HNSCC is a very heterogeneous disease a single factor would not be able to predict the treatment outcome. In paper I we explore a panel of predictive factors using a point system, called the number of negative points (NNP), in which we could combine both proteins and genetic variations in an attempt to find a set of markers that could predict the intrinsic cisplatin sensitivity (ICS). The expression level of EGFR, Hsp70, Bax, Bcl-XL, survivin, and COX-2 was determined in 39 HNSCC cell lines. Moreover, the p53, MDM2, FGFR4, XPC, XPD, XRCC1, and XRCC3 genes were analyzed for the presence of specific single nucleotide polymorphisms (SNPs). Pearson's correlation tests showed that EGFR was the only protein that alone correlated to ICS $(r=0.388, \mathrm{P}=0.015)$. The strongest correlation to ICS was found when combining SNPs in XRCC3 and XPD with the expression of EGFR, Hsp70, Bax, and Bcl-2 using the NNP system $(\mathrm{r}=0.614 \mathrm{P} \leq 0.001)$.

In paper II we assess the intrinsic radiosensitivity (IR), the ICS, and the intrinsic cetuximab sensitivity (ICmabS) as well as their combinations in $25 \mathrm{HNSCC}$ cell lines established from HNSCC biopsies taken at the Department of Otorhinolaryngology and Head and Neck Surgery at Linköping University Hospital. Furthermore we investigate the EGFR status (consisting of EGFR gene copy number, EGFR mRNA, EGFR protein, pEGFR), pAkt and mRNA levels of the seven known EGFR ligands. No correlation was found between the 
different treatment sensitivities. Cetuximab treatment response was significantly correlated to epiregulin (EREG) mRNA expression $(\mathrm{r}=-0.408, \mathrm{P}=0.043)$. Cetuximab resistant cell lines tended to have low levels of pEGFR $(\mathrm{P}=0.13)$ while resistant cell lines had a significantly lower expression of EGFR protein $(\mathrm{P}=0.04)$ and tended to have decreased levels of pAkt $(\mathrm{P}=0.13)$ and amphiregulin (AREG) mRNA $(\mathrm{p}=0.18)$.

In paper III the functional importance of EGFR ligands in relation to proliferation and cetuximab sensitivity was investigated. Here we tried to diminish the tumor heterogeneity by selecting three cell lines that are derived from the same anatomical location but display different ICmabS. Signaling through the EGFR was stimulated with recombinant EGF, AREG or EREG or reduced by siRNA-mediated silencing of the aforementioned EGFR ligands. EGF downregulation suppressed the proliferation of all investigated tumor cell lines whereas the response to an increased level of EGF differed between EGFR overexpressing and EGFR non-overexpressing cell lines. Furthermore, tumor cells consistently displayed increased cetuximab resistance upon the addition of EGF, whereas EGF silencing was associated with an improved cetuximab response. The data regarding AREG and EREG were inconclusive.

In paper IV we wanted to validate in vitro drug sensitivity testing of HNSCC cell lines in an in vivo xenograft model, and to identify treatment-induced changes in the EGFR signaling pathway that could be used as markers for cetuximab treatment response. In vitro ICmabS for the HNSCC cell lines UT-SCC-14 and UT-SCC-45 was established using a crystal violet assay. In order to determine the corresponding in vivo sensitivity, UT-SCC-14 and UT-SCC45 xenografts were generated in female BALB/c (nu/nu) nude mice. Mice were given three injections of intraperitoneal cetuximab or PBS and the tumor volume was recorded continuously. The expression of EGFR, pEGFR, pSrc, and Ki67 in the tumor tissue was investigated by immunohistochemistry. The in vitro sensitivity was reproduced in the in vivo model. Furthermore a clear reduction of EGFR, pEGFR, and pSrc after cetuximab treatment was noted in UT-SCC-14, the cetuximab sensitive cell line while the cetuximab resistant UTSCC-45 showed a slight increase in EGFR, pEGFR and pSrc.

In conclusion, the EGFR ligand EGF is a potential predictive marker of poor cetuximab response and a possible treatment target. Moreover, treatment-induced downregulation of EGFR and pEGFR is associated with a good cetuximab response. 


\section{POPULÄRVETENSKAPLIG SAMMANFATTNING}

Maligna tumörer i öron, näsa och halsområdet utgörs till 90\% av skivepitelcancer. Tumörerna uppkommer genom att celler i slemhinnan börjar dela sig okontrollerat. Varje år drabbas cirka 600000 personer i världen av denna cancerform, som orsakar stort lidande hos patienterna. Förutom kraftig smärta påverkas basala funktioner som andning, tal och sväljning. Syn, lukt och smak kan också påverkas av tumörväxten, eller av behandlingen som ges för att bekämpa cancern.

Ofta kräver tumörerna en kombination av olika behandlingar såsom kirurgi, cellgifter (som för det mesta är cisplatinbaserad), och strålbehandling. Ett behandlingsalternativ som tillkommit de senaste 10 åren är cetuximab, en målsökande antikropp som binder till och blockerar EGF-receptorer i cellmembranet. Tumörceller har ofta en högre mängd EGFreceptorer än normala celler. När en ligand binder till EGF-receptorn startas signalkedjor inne i cellen som stimulerar tumörens tillväxt.

Behandling med strålning och cellgift har inte bara plågsamma, utan även farliga biverkningar. Trots att maximal behandling ges finns det tumörer som är resistenta mot behandlingen, eller återkommer efter avslutad behandling. Det finns flera kända proteiner och genetiska förändringar som kan ha betydelse för hur känslig tumören är för behandling, men ännu finns ingen möjlighet att förutsäga vilka patienter som kommer att gynnas av den plågsamma behandlingen och vilka patienter som får den i onödan. Tumörer skiljer sig sinsemellan mycket åt beträffande vilka proteiner och genetiska variationer som förekommer. Därför har vi valt att undersöka hur mängden EGF-receptorer och andra proteiner som är inblandade i tumörcellernas tillväxt samspelar med genetiska variationer beträffande känslighet för strålning, cisplatin och cetuximab. Målet är att hitta markörer som förutsäger hur känslig varje enskild patientents tumör är för de olika behandlingarna.

I artikel I undersökte vi om förekomst av olika proteiner och genetiska variationer i tumörceller kan förutsäga känsligheten för behandling med cisplatin. Känsligheten för cisplatin mättes i 39 cellinjer som odlats fram från patienter med skivepitelcancer i huvud och halsregionen. Cisplatinkänsligheten korrelerades sedan till cellernas förmåga att tillverka proteiner som stimulerar tumörväxt. Mängden EGF-receptorer i cellerna visade sig vara den enda faktor som korrelerade till cisplatinkänslighet. Celler som hade två specifika genetiska variationer (inom gener för XRCC3 och XPD) och högt EGFR uttryck, samt höga nivåer av tre andra proteiner (Hsp70, Bax och Bcl-2), visade sig ha störst känslighet för cisplatin. Det fanns inget samband mellan känslighet för cisplatin och strålning. 
Artikel II undersökte hur mängden av olika proteiner påverkade cellernas känslighet för cisplatin, strålning och cetuximab i 25 cellinjer odlade från biopsier som tagits på öronkliniken i Linköping. Cancerceller med få EGF-receptorer visade sig vara mindre känsliga för cisplatin. Känsligheten för cetuximab var högre i celler med hög halt av mRNA för epiregulin och lägre i celler vars EGF-receptorer var fosforylerade. Flera andra proteiner hade betydelse för cellernas känslighet för behandling. Vi tolkar detta som att flera av de proteiner vi analyserade skulle kunna tjäna som prediktiva markörer för behandlingskänslighet.

I artikel III undersökte vi faktorer som påverkar känslighet för cetuximab i tre cellinjer från olika patienter med tumörer i tungan. De tre valda cellinjerna hade olika känslighet för cetuximab samt varierande mängd EGFR. Vi undersökte hur tillväxt och känslighet för cetuximab påverkades när EGF-receptorn stimulerades med tre olika ligander. Vidare undersökte vi vad som hände när vi blockerade cellens egen produktion av dessa ligander. I alla tre cellinjer minskade celldelningstakten när mängden av receptorliganden EGF minskade. I celler som stimulerades med EGF ökade tillväxten i de fall där cellen hade ökad mängd receptorer. Känslighet för cetuximab minskade när EGF tillsattes och ökade när mängden EGF sänktes. Vår hypotes är att ökad mängd EGF i tumören är en potentiell markör för minskad känslighet för cetuximab. Blockering eller minskning av EGF skulle kunna vara en framkomlig väg i sökandet efter nya behandlingar mot skivepitelcancer.

Artikel IV undersöker hur väl känslighet för cetuximab i cellinjer förhåller sig till cetuximabkänsligheten hos tumörer i möss. Vi kartlägger även vilka proteiner i cellens signalsystem som påverkas under cetuximabbehandling. Tumörceller från cellinjer som var antingen känsliga eller resistenta för cetuximab injicerades i möss och fick växa till tumörer. Cellinjerna och mössen behandlades med cetuximab. Känsligheten för cetuximab i cellodlingen visade sig överensstämma med känsligheten i musmodellen. Vidare observerades att cetuximab orsakade en minskning av EGF-receptorer och fosforylerade EGF-receptorer i tumörer som var känsliga för cetuximabbehandling. Denna minskning av EGF-receptorer under cetuximabbehandling skulle kunna vara ett sätt att förutspå om en patient bör fortsätta alternativt avbryta sin behandling.

I framtiden hoppas vi att en panel med markörer kommer att tillåta oss att skräddarsy behandling för varje enskild patient med cancer inom huvud och hals regionen. På det sättet skulle man kunna ge den mest effektiva behandlingen och samtidigt minska biverkninsprofilen. 


\section{LIST OF PAPERS}

This thesis is based on the following papers, which will be referred to in the text by their roman numbers I-IV:

I Lovisa Farnebo, Adam Jedlinski, Anna Ansell, Linda Vainikka, Lena Thunell, Reidar Grénman, Ann-Charlotte Johansson, and Karin Roberg (2009)

Proteins and single nucleotide polymorphisms involved in apoptosis, growth control and DNA repair predict cisplatin sensitivity in head and neck cancer cell lines

International Journal of Molecular Medicine 2009:Oct;24(4):549-556

II Adam Jedlinski, Anna Ansell, Ann-Charlotte Johansson, and Karin Roberg

EGFR status and EGFR ligand expression influence the treatment response of head and neck cancer cell lines

Journal of Oral Pathology and Medicine 2012:Jan;42(1):26-36

III Anna Ansell, Adam Jedlinski, Ann-Charlotte Johansson, and Karin Roberg

Epidermal growth factor is a potential biomarker for poor cetuximab response in tongue cancer cells

Accepted for publication in Journal of Oral Pathology and Medicine. 2015

IV Adam Jedlinski, Stina Garvin, Ann-Charlotte Johansson, Per-Henrik Edqvist, Fredrik Ponten, and Karin Roberg

Cetuximab sensitivity of head and neck squamous cell carcinoma xenografts is associated with treatment-induced reduction of EGFR, pEGFR and pSrc

Manuscript 


\section{ABBREVIATIONS}

Akt $\quad \mathrm{V}$-akt murine thymoma viral oncogene homolog

AREG Amphiregulin

Bax Bcl-2 associated $\mathrm{X}$ protein

Bcl-2 B-cell lymphoma 2

BTC Betacellulin

COX-2 Cyclooxygenase 2

DNA Deoxyribonucleic acid

DSB Double strand break

EGF Epidermal growth factor

EGFR Epidermal growth factor receptor

EPGN Epigen

EREG Epiregulin

FAK Focal adhesion kinase

FGFR4 Fibroblast growth factor receptor 4

HB-EGF Heparin-binding EGF-like growth factor

HNSCC Head and neck squamous cell carcinoma

HPV Human papilloma virus

HSP70 Heat shock protein 70

IAP Inhibitor of apoptosis

ICmabS Intrinsic cetuximab sensitivity

ICS Intrinsic cisplatin sensitivity

IR Intrinsic radiosensitivity

$\mathrm{kDa} \quad$ Kilodalton

Ki67 Antigen identified by monoclonal antibody Ki-67

KRAS Kirsten rat sarcoma viral oncogene homolog

MAPK Mitogen activated protein kinase

MDM2 Murine double minute 2

MRI Magnetic resonance imaging

mRNA Messenger RNA

mTOR Mechanistic target of rapamycin

NER Nucelotide excision repair

NNP Number of negative points 
NOK Normal oral keratinocytes

PCR Polymerase chain reaction

PFA Paraformaldehyde

PI3K Phosphatidylinositol 3 kinase

qPCR Quantitative polymerase chain reaction

$\mathrm{Rb} \quad$ Retinoblastoma 1

$\mathrm{Rh} \quad$ Recombinant human

RT Radiotherapy

SDS Sodium dodecyl sulfate

siRNA Small interfering ribonucleic acid

SNP Single nucleotide polymorphism

Src V-src sarcoma (Schmidt-Ruppin a-2) viral oncogene homolog

STAT Signal transducer and activator of transcription

TGF $\alpha \quad$ Tumor growth factor alpha

TNM Tumor, node, metastasis

$\mathrm{XPC} \quad$ Xeroderma pigmentosum complementum group $\mathrm{C}$

XPD Xeroderma pigmentosum complementum group D

XRCC1 X-ray repair cross-complementing group 1

XRCC3 X-ray repair cross-complementing group 3 


\section{INTRODUCTION}

\section{Cancer of the head and neck}

Primary head and neck malignancies can arise in virtually any anatomical structure in this region. However the majority (about $90 \%$ ) of malignancies develop from the epithelium that lines the upper aerodigestive tract forming head and neck squamous cell carcinoma (HNSCC). This is the only patho-anatomic diagnosis studied in this thesis. The five year overall survival is approximately $50 \%$ (Leemans et al. 2011; Thomas et al. 2005) and although recent advances in our understanding of this disease have been made, none have altered our current treatment strategies and furthermore none have impacted the overall survival in a beneficent way.

HNSCC is a disease that impacts negatively on the quality of life in the individual patient. The various symptoms and degree of life quality impairment is mainly caused by the tumor location and the local destruction it causes in the affected and surrounding tissue, usually taking a toll on one or several of our senses. Tumors forming in the maxillary sinus or nasal cavity may invade and displace a patient's orbital cavity causing in effect blindness. Tongue tumors can cause speech impairment, obstruct the airways affecting breathing and impede swallowing. Apart from more site-specific symptoms patients also experience pain, catabolic breakdown of the entire body, distant metastatic disease etc. Even the treatment strategies that we employ are invasive and they further diminish the patient's quality of life.

Patients present themselves at the clinician's office with various symptoms. Some can be very specific, for example hoarseness in laryngeal cancer, while others present themselves rather late in their disease with a mass on their neck after having it for several weeks. This is seen quite often in tonsil cancer cases where the primary tumor in the gland might only be visible under the microscope. Unfortunately approximately half of the patients are presenting themselves at a late stage in their disease (stage III or IV) when the tumor has grown in size or started to spread to the lymph nodes or even further, most commonly the lungs. This has a great negative impact on the prognosis.

\section{Risk factors}

The main risk factors for HNSCC are alcohol and smoking. Together they increase the risk for developing HNSCC by a factor of 50 (Blot et al. 1988; Vineis et al. 2004). The abuse of 
alcohol and smoking also explains the male predominance among HNSCC patients (Blot et al. 1988; Vineis et al. 2004). Betel nut chewing is a very common cause for oral cancers in Asia. Also different viruses are known to increase the risk for HNSCC; Epstein-Barr virus causes cancer in the nasopharynx and human papilloma virus induces tonsil and base of tongue cancers. Environmental exposure may also be a risk factor, e.g., hard wood dust exposure has been linked to nasal cavity squamous cell cancer.

\section{Treatment}

Treatment of HNSCC depends on several factors. Not only does the size and location of the tumor play a role but also several other factors ranging from the expertise and treatment modalities available, general condition and lifestyle factors (smoking, alcohol abuse etc.) of the patient, and the patients acceptance to various treatments.

Patients undergo investigation with a biopsy from the primary tumor for histopathological classification, investigation of the local and regional spread of the tumor via computed tomography and/or magnetic resonance imaging (MRI), fine needle aspiration of regional lymph nodes, and also usually a computed tomography of the lungs. This allows us to classify the patient's tumor according to the TNM (tumor, node, metastasis) system and finally based on the TNM the overall cancer stage is determined. Based on this a treatment strategy is then placed into play.

Although there are new forms of treatment options available, such as targeted therapy using epidermal growth factor receptor (EGFR) targeting antibodies (cetuximab), none have actually changed the survival rates in a dramatic way. A factor contributing to this could be the problem of tumor heterogeneity that HNSCC displays. Two patients with a similar anatomically located and staged HNSCC can react completely differently to the same treatment plan. Let us take two patients with cancer of the mobile part of the tongue graded as T2N0M0 as an example. Standard treatment in Linköping would be preliminary radiotherapy (RT) followed by surgical resection. One of the patients could fully respond to the given RT and the tumor disappears both macro- and microscopically whereas the other patients tumor actually increases in size during the preoperative treatment period. In the second case a different treatment strategy with surgery as the first line treatment followed by RT, may have been beneficial. Some sort of predicting mechanisms would be very helpful in deciding these treatment options. 


\section{Surgery}

Surgery has been the main treatment modality for HNSCC. It has however several limitations such as tumor location, size and spread. Resection is possible when a tumor can be removed with surrounding healthy tissue. The cost of this has to be within reason regarding the patient's quality of life following surgery. Advances in this field have been made with the help of vascular free flaps, however this has not improved the overall survival (Shah 2007). Although surgery as a single treatment modality is usually employed in early stage small cancers, such as T1N0M0 mobile tongue cancers, it most often plays a part in multi modality treatments. It is worth mentioning that not all early cancers are treated with surgery. Tonsil cancer and base of tongue cancer fall into this category.

\section{Radiotherapy}

RT can be given as a single modality treatment in for example tonsil cancer or stage I-III laryngeal cancer. It is also given in combination with surgery, either pre- or post-surgery. Via formation of reactive oxygen species RT induced irreparable DNA damage, such as double strand breaks, resulting in cell cycle arrest, apoptosis or terminal senescence (Chen \& Nirodi 2007).

RT can be given in a variety of ways delivering different dosages once or twice daily. A lot of research has been focused on trying to optimize dosage plans resulting in accelerated fractionation, hyperfractionation (Horiot et al. 1992; Zackrisson et al. 2011), and intensitymodulating radiotherapy (Argiris et al. 2008), however, the benefits of these treatments over conventional RT are still debatable (Peters 2007).

Side effects of RT are well documented and vary to some extent from patient to patient. The main problems are mucositis in the oral cavity and pharynx, hoarseness and swallowing disabilities. Patients often need assistance in receiving nutrition via the help of a nasogastric tube or gastrostomy.

\section{Chemotherapy}

Chemotherapy is mainly administered in patients that have locally advanced HNSCC. It usually is accompanied by RT and in some cases also surgery. Addition of chemotherapy to RT enhances the overall 5-year survival by $4 \%$ in the treatment of non-metastatic HNSCC (Pignon et al. 2000). There are several different chemotherapeutic agents however cisplatin, a platinum-containing compound, is preferred within HNSCC treatment. Cisplatin enters cells via diffusion and interacts with the cellular DNA causing inter- and intra-strand crosslinks 
resulting in activation of DNA repair, cell-cycle arrest and/or apoptosis (Kelland 2007; Rosenberg et al. 1969). Side effects range from nausea and vomiting to neutropenia, neuro-, nephro-, and ototoxicity (Boulikas \& Vougiouka 2003). Due to the side effects not all patients are candidates for cisplatin treatment and the patients general condition plays a vital part in selecting this treatment option.

\section{Epidermal growth factor receptor targeted therapy}

The epidermal growth factor receptor is overexpressed in the majority of HNSCC tumors (Mehra et al. 2008). This feature makes it a suitable candidate for targeted therapy. Cetuximab is a monoclonal antibody directed towards the ligand binding site of EGFR. There are several other substances that target EGFR, such as gefitinib, erlotinib, and afatinib, however, cetuximab is the only approved EGFR targeting drug for the treatment of HNSCC in Sweden. Bonner et al. has shown its usefulness in the treatment of HNSCC patients in combination with RT; the overall survival was improved by 20 months when compared to RT alone (Bonner et al. 2010; Bonner et al. 2006). In Linköping cetuximab treatment is reserved for advanced stage tumors.

Cetuximab binds to EGFR in a reversible, competitive fashion and with a higher affinity as compared to the EGFR ligands. Upon binding to the EGFR activation of the intracellular tyrosine kinase domain of EGFR is prevented and therefore further downstream signaling is inhibited (Jaramillo et al. 2006; Li et al. 2008). These blocked receptors are then internalized and degraded depleting EGFR from the cell membrane. This is a fundamental mechanisms in cetuximab-induced growth inhibition in vivo (Sigismund et al. 2005).

Cetuximab has known side effects such as skin toxicity causing changes in hair, nails and a skin rash. Interestingly the severity of the rash that patients experience strongly correlates to the effectiveness of the treatment (Bonner et al. 2010). The rash seems to be a favorable prognostic marker.

One interesting question remains; could cetuximab treatment be more favorable in patients with earlier staged tumors? Perhaps treatment policies hinder the benefit we could have from this therapy. Further clinical studies are required to investigate the full treatment potential of cetuximab.

\section{Combined treatment modality}

In the clinical setting we always try to treat patients with the most aggressive treatment strategies that are appropriate for that particular patient. Apart from the earliest stages of 
HNSCC all tumors are treated with multimodality strategies. For example, in Linköping a 3 $\mathrm{cm}$ tumor on the mobile part of the tongue will undergo preoperative RT and then surgical resection. A base of tongue squamous cell cancer would be treated with RT and chemotherapy while an advanced laryngeal cancer with engagement of the thyroid cartilage would be treated primarily with surgical resection in the form of a total laryngectomy followed by RT or chemoradiotherapy. The choice of treatment is governed by several factors such as the tumor size and spread, its location, the patient's general health status and also treatment traditions. Unfortunately it is not uncommon that a tumor more than doubles in size during a preoperative treatment with RT. In effect our treatment strategy fails in these cases. Until this day we have no predictive markers in our clinical practice that could allow us to further tailor treatment plans on a more individual basis. 


\section{Predictive markers}

\section{The epidermal growth factor receptor}

The epidermal growth factor receptor (EGFR/HER1/ERBB1) is a tyrosine kinase transmembrane cell surface receptor with an extracellular ligand binding domain and an intracellular tyrosine kinase domain. It is a member of the ErbB protein kinase family and is primarily found on the cells with epithelial, mesenchymal, and neuronal origin. The ErbB family consists of four members, 1) EGFR/ERBB1/HER1, 2) ERBB2/HER2/NEU, 3) ERBB3/HER3, and 4) ERBB4/HER4. It is worth mentioning that ERBB2 has no known ligand while ERBB3 has impaired intracellular kinase ability.

EGFR in its inactive, ligand free form, exists as a monomer however after ligand binding it either forms a homodimer with another EGFR molecule or heterodimer with another member of the ErbB-family. This dimerization then activates the intracellular kinase activity by autophosphorylation of the catalytic domain in EGFR further transducing the signal in a downstream fashion (Downward et al. 1984). There are five main downstream pathways;

1. the mitogen-activated protein kinase (MAPK) which stimulates gene expression and cellcycle progression.

2. phospholipase $\mathrm{C}$ which regulates cell transformation, differentiation and apoptosis

3. phosphatidylinositol 3-kinase/v-akt murine thymoma viral oncogene homolog (PI3K/Akt) which stimulates angiogenesis, tumorigenesis and inhibition of apoptosis

4. Signal transducer and activator of transcription (STAT) which stimulates survival, proliferation and oncogenesis and

5. Src/Focal adhesion kinase (FAK) that in tumors helps to invade the surrounding tissues (Laurent-Puig et al. 2009).

The pathways are very complex with a lot of cross talk both in an inhibitory and stimulatory manner. The activation is driven by seven known EGFR ligands including epidermal growth factor (EGF), amphiregulin (AREG), epiregulin (EREG), tumor growth factor alpha (TGF $\alpha$ ), epigen (EPGN), betacellulin (BTC), and heparin-binding EGF-like growth factor (HB-EGF). All of these bind to EGFR however not all of the members of the ErbB-family are receptors for these ligands. The ErbB2 has no known ligand, ErbB3 binds neuregulin 1 and 2 while ErbB4 binds betacellulin, HB-EGF, epiregulin and neruregulin 1-4 (Wilson et al. 2009). These ligands in general exert their actions over short distances from their site of origin. They act in an autocrine, juxtacrine and paracrine fashion (Blobel 2005). 
The extracellular domain of EGFR is composed of 4 domains. Domains 1 and 3 bind the ligands. Upon binding a conformation change occurs and part of domain 2 is exposed. This part of the extracellular portion of EGFR is responsible for dimerization (Burgess et al. 2003). The monoclonal antibody cetuximab binds only to domain 3. This complex does not induce any conformational changes in the cetuximab-EGFR complex. The binding site for cetuximab overlaps the ligand-binding site of domain 3 thereby blocking the receptor in its monomeric inactivated form ( $\mathrm{Li}$ et al. 2005).

EGFR and its family play a role in cancer formation and subsequently in the treatment options. Overexpression of EGFR occurs within cancers of the lung, colon and rectum, breast, and stomach where treatment with a variety of different tyrosine kinase inhibitors is already in practice. Within HNSCC there is a clear overexpression in about $90 \%$ of all cases (Mehra et al. 2008). This overexpression is shown to be an indicator of poor prognosis (Ang et al. 2002; Grandis \& Tweardy 1993) and resistance to chemotherapeutic agents (Ang et al. 2002).

Bonner et al investigated the effects of adding cetuximab to RT when treating HNSCC. An increase in overall survival (OS) by 20 months was noted in the patient group receiving a combination of cetuximab and RT compared to RT alone (OS 49 vs 29,3 moths respectively) (Bonner et al. 2010; Bonner et al. 2006).

The mechanisms employed by tumors to avoid treatment effects of cetuximab are not fully understood. Several possibilities exist from mutations in the EGFR gene, such as the EGFR variant III where the ligand binding domain is missing and the receptor is permanently in its activated form (Sok et al. 2006) to the formation of EGFR heterodimers and/or crosstalk with HER2, HER3, cMET, and insulin-like growth factor 1 receptor (IGF-1) (Wheeler et al. 2008). Crosstalk occurs to a great extent within the ErbB family. An example of this would be the PI3K/Akt pathway. It is known that the regulatory subunit of PI3K, p85, binds to several places on the intracellular domain of ErbB3 while no data supports the binding of this subunit to EGFR (Wilson et al. 2009). Hence, blocking EGFR with cetuximab does not prevent ErbB3 dimerizing and subsequently activating the PI3K/Akt pathway. The signal for tumorigenesis, angiogenesis and inhibition of apoptosis completely escapes in this case the treatment effects of cetuximab.

\section{Akt}

Akt or protein kinase $\mathrm{B}(\mathrm{PKB})$ is a protein-serine/threonine kinase, which participates as a downstream signal transducer in the EGFR signaling cascade. It participates in the PI3K-Akt pathway, which stimulates angiogenesis, tumorigenesis and inhibition of apoptosis. As 
mentioned earlier ErbB3 plays a major role in activation of this pathway due to multiple $\mathrm{p} 85$ binding sites on the intracellular portion of ErbB3. This subunit activates PI3K which in turn phosphorylates phosphatidylinositol-4,5-biphosphate (PIP2) converting it to phosphatidylinositol-3,4,5-triphosphate (PIP3). PIP3 attracts Akt to the cell membrane where it is activated via phosphorylation (Cantley 2002; Luo et al. 2003). Active Akt in turn phosphorylates and activates mammalian target of rapamycin (mTOR). The activated mTOR participates in several cellular processes including that of cell survival (Simpson et al. 2014). Activated Akt also phosphorylates MDM2 and Bcl2-associated death promotor (BAD) (Engelman et al. 2006), which is a member of the Bcl-2 family described below. BAD is a pro-apoptotic protein that in its phosphorylated form is inhibited from promoting apoptosis while phosphorylated MDM2 functions to inhibit p53.

\section{Heat shock protein 70 (Hsp70)}

Heat shock proteins were given their name after the discovery that these proteins were induced in cells by exposure to heat. It was also discovered that other forms of stress induced the same group of proteins, however, the name remained. These proteins allow the cell to cope with the stress that they are subjected to (De Maio 1999). Hsp70, so named after its molecular weight of $70 \mathrm{kDa}$, is upregulated in $\mathrm{HNSCC}$ and functions in a protective manner against the surrounding environment (Weber et al. 2007). Inactivation of Hsp70 increased the amount of remaining DNA double strand breaks after exposure to radiation, which in turn lead to increased apoptosis. This supports the theory that increased Hsp70 protects the cells from radiation and apoptosis thereby aiding the cancer cell in their fight against radiotherapy. Hsp70 has also been linked with resistance to chemotherapy (Garrido et al. 2006).

\section{Bcl-2 family of apoptosis regulator proteins}

During apoptosis, cellular stress signals, either extrinsically mediated by death receptors or intrinsically mediated by for example DNA damage due to radiation, converge on the mitochondria to release cytochrome $\mathrm{c}(\mathrm{Cyt} \mathrm{C})$ into the cytoplasm. In the cytoplasm Cyt $\mathrm{C}$ is involved in the activation of caspases, which are assassins of apoptosis (Fesik \& Shi 2001). The actual release of Cyt $\mathrm{C}$ from the mitochondria is orchestrated by mitochondrial outermembrane permeabilization. This permeabilization of the outer-membrane of the mitochondria is usually the point of no return and is regulated by proteins of the Bcl-2 family. This family of proteins has both pro- and anti-apoptotic members. The balance between these will determine if the pro-apoptotic members BCL-2 antagonist killer (Bak) and BCL-2- 
associated $\mathrm{X}$ protein (Bax) will form a pore in the outer mitochondrial wall thereby making it permeable (Strasser et al. 2000).

Wilson et al noted a $13 \%$ overexpression of the anti-apoptotic protein Bcl-2 in HNSCC tumors and it is contemplated to be more extensively overexpressed in more advanced and aggressive cancers (Wilson et al. 2001). Bcl-2 is further involved in a number of malignancies such as melanoma, breast, prostate, and lung carcinomas. Disturbances within the Bcl-2 family can therefore hinder apoptosis and allow pathogenesis of cancers to occur. These disturbances can furthermore hinder the effects of anticancer therapies.

In this thesis we studied the anti-apoptotic protein b-cell lymphoma-2 (Bcl-2) and proapoptotic members Bax and b-cell lymphoma-extra large (Bcl-xl).

\section{Survivin}

Survivin, one of 7 members of the inhibitor of apoptosis protein (IAP) family, is a key regulator in cell division, cell promotion and cell survival. Survivin is almost untraceable in most terminally differentiated normal tissues while highly expressed during embryonic and fetal development. Most likely, survivin has a governing role in sustaining tissue and organ homeostasis and differentiation (Adida et al. 1998; Altieri 2008). In contrast it is known that most human tumors (including HNSCC), and also some non-malignant diseases such as osteoarthritic human cartilage (Lechler et al. 2011), psoriasis (Dallaglio et al. 2012), and rheumatoid arthritis (Bokarewa et al. 2005), have an abundance of survivin (Sah et al. 2006).

The regulation of survivin expression is intricate. Several proteins control survivin at the transcription level. Worth mentioning here in this thesis is the p53-driven survivin gene suppression that indirectly via the help of DNA methyltransferase 1 (DNMT1) methylates the survivin promoter thereby inhibiting transcription of survivin (Estève et al. 2005). Downregulation of survivin further stabilizes p53 leading to an augmentation loop for survivin suppression.

On the contrary survivin expression and endurance has been linked to several proteins and pathways. Insulin-like growth factor $1 /$ mammalian target of rapamycin (mTOR) signaling pathway up-regulates survivin gene transcription while heat shock proteins 60 and 90 play a role in stabilizing survivin, by protecting against proteasome dependent degradation (Fortugno et al. 2003; Ghosh et al. 2008; Mita et al. 2008).

Inhibition of apoptosis by survivin occurs by both caspase-dependent and caspaseindependent pathways. In the caspase-independent pathway survivin interferes with mitochondrial apoptosis-inducing factor (AIF). AIF is a mitochondrial protein that is released 
from the mitochondria upon apoptosis triggering. It finds its way to the cell nucleus where it induces DNA fragmentation (Liu et al. 2004). In the caspase-dependent pathway, survivin interacts with other molecules such as hepatitis B X-interacting protein (HBXIP) and x-linked IAP (XIAP), forming complexes that inhibit caspase-9.

Vascular endothelial cells do in fact express survivin under normal physiological conditions.

This expression is enhanced in tumor endothelial angiogenesis further emphasizing the protective role of survivin in tumor growth and development.

Survivin is naturally an interesting target in cancer treatment due to its tumor promoting functions and its abundance in human tumors. Several studies show varying degrees of success upon treatment of tumors with various anti-survivin agents. However, one factor seems to be in common, anti-survivin treatments are well tolerated by their hosts.

\section{Cyclooxygenase-2 (COX-2)}

COX-2 is a key enzyme in the conversion of arachidonic acid to prostaglandins and interleukins. It is responsible for the inflammatory reaction in tissues. Unlike its closely related isoform COX-1, COX-2 is expressed at a very low level in normal tissues. Its further a target for ongoing studies in chemoprevention for developing HNSCC. This is mainly because COX-2 is not only overexpressed in the tumor but also in the surrounding healthy epithelium (Chan et al. 1999; Hawk et al. 2002; Liu et al. 2008). Furthermore an up regulation is present in premalignant lesions such as leukoplakia and dysplasia (Saba et al. 2009). In vitro studies have suggested that COX-2 inhibition delays the growth of HNSCC cell lines (Ondrey et al. 1996; Panje 1981; Scioscia et al. 1997) while one study has shown that a 12 week long treatment with celecoxib, a COX-2 selective nonsteroidal anti-inflammatory drug, improves premalignant lesions by decreasing the degree of dysplasia in biopsies (Wirth et al. 2008). It has also been noted that tumors that overexpress COX-2 showed an increased radiation resistance (Shin et al. 2005; Terakado et al. 2004) and increase resistance towards chemotherapy (Koki et al. 1999) due to increased resistance towards apoptosis (Thomas et al. 2005).

\section{P53 and murine double minute 2 (MDM2)}

The p53 pathway is no doubt one of the more famous pathways within tumor biology. Encoded by the TP53 gene, p53 functions as a guardian of the genome. It is a tumor suppressor gene that after activation due to cellular stress, such as DNA damage or hypoxia, controls the outcome or fate of the cell. It does this by acting as a transcription factor inducing 
or suppressing the expression of genes involved in apoptosis, senescence, and cell cycle arrest. It has been shown recently that the p53 function spectrum is broader. It has now been implicated in metabolism, necrosis, autophagy, reactive oxygen species accumulation and stem cell maintenance (Hager \& Gu 2014). It is also the most frequently mutated gene within HNSCC (Stransky et al. 2011) with the rate of mutations being approximately $50 \%$. Mutations of p53 promote resistance to cisplatin and radiotherapy within HNSCC (Ohnishi et al. 2002). This supports the result that HNSCC patients with wildtype p53 have better overall survival than patients with p53 mutation (Poeta et al. 2007).

A mutation within p53 results in loss of habitual p53 functions and moreover these mutated proteins display a dominant-negative activity towards remaining wild-type p53. Furthermore some mutations, so called gain of function mutations, results in acquisition of new functions, such as stimulation of angiogenic factors, metastasis, inactivation of other members of the p53 pathway, and resistance to therapy (Muller \& Vousden 2013) resulting in cancer progression.

Other mechanisms of inactivation of wild-type p53 pathways are known. Certain DNA viruses encode proteins that bind and thereby inactivate p53. The E6 protein of the human papilloma virus type 16 and18 is one such example. This is documented in cervical cells (Hengstermann et al. 2001) and is considered one of the steps in cervical cancer formation (Asiaf et al. 2014). Other more domestic cellular proteins can also inactivate the p53 protein. Murine double minute 2 or MDM2 is a negative controller of p53. It functions by facilitating the transport of p53 out of the cell nucleus by binding directly to it and being a ubiquitin ligase it marks the p53 via ubiquitylation and directs it to ubiquitin-dependent proteolysis in the proteasome (Kubbutat et al. 1997).

In summary, the majority of malignant tumors most likely have a dysfunctional p53 pathway, either due to mutations of the p53 gene or a boosted degradation of the wild-type molecule.

\section{Fibroblast growth factor receptor 4 (FGFR4)}

FGFR4, like the rest of the 3 remaining members of the fibroblast growth factor receptor (FGFR) family, is a receptor tyrosine kinase. The FGFR family is involved in natural cellular processes such as cell growth, tissue development and differentiation, angiogenesis, tissue repair and survival. Any derangement of these functions can lead to cancer or developmental flaws. The four members of this family all have a similar structure comprised of 1) three extracellular domains that resemble immunoglobulin in structure, 2) a cell membrane 
spanning domain, and 3) a cytoplasmic tyrosine kinase domain (Powers et al. 2000). All four receptors bind the 23 different ligands known as the fibroblast growth factors (Chen et al. 2005).

The FGFR family has been involved in several human cancers such as cervix, bladder and breast (Streit et al. 2004). Interestingly enough, the actual specific function of FGFR4 is still unknown. A single nucleotide polymorphism (SNP) changing the sense codon 388 of the FGFR4 gene from a glycine (Gly) to an arginine (Arg) has been found in approx. $50 \%$ of the population. It has no clear correlation to tumor formation however it is loosely connected with a more aggressive tumor progression and metastasis (Bange et al. 2002). This SNP is associated with a worse prognosis in breast and colon cancer (Bange et al. 2002), sarcomas (Morimoto et al. 2003), and in HNSCC (da Costa Andrade et al. 2007; Streit et al. 2004). Moreover, the Gly388 allele has been reported to have a protective function in cancer progression which seems to be absent in the Arg388 allele. In a study where 35 HNSCC cell lines were investigated the FGFR4 Arg388 allele was proposed to play a role in cisplatin sensitivity (Ansell et al. 2009). Additionally, Farnebo et al. demonstrated in a retrospective study that HNSCC patients with the Arg388 allele had a significant improved overall survival compared to the wild type allele in 40 patients that received RT as a single or combined treatment modality (Farnebo et al. 2013).

\section{Single nucleotide polymorphisms in the DNA repair genes XPC, XPD, XRCC1, and $\mathrm{XRCC3}$}

Our genome undergoes a massive 25000 spontaneous base damages in every human cell, every day (Friedberg 2001). When damage occurs a series of checkpoints in the cell cycle are activated, DNA repair genes are upregulated, and apoptosis may be initiated. The cell cycle arrests in $G_{1}$ in order to avoid damaged DNA replication. SNPs in four DNA repair genes were studied in this thesis.

Xeroderma pigmentosum complementum group $\mathrm{C}$ (XPC) and xeroderma pigmentosum complementum group D (XPD) both participate in the nucleotide excision repair (NER) pathway. This pathway is important in ultra violet light damage to the DNA which often results in bulky DNA adducts. The damaged section of the strand of the DNA is excised and DNA polymerase uses the undamaged complementary strand to restore the DNA.

There are more than 100 polymorphic variants of the XPC gene. The most common and best studied one is the XPC Ala499Val polymorphism where an alanine is replaced with a valine. This SNP is linked to an increased risk for developing breast, bladder, esophagus, lung, skin, 
and head and neck cancer (Francisco et al. 2008). SNPs in XPD Lys751Gln have been studied and correlated to increased risk for HNSCC. In a retrospective study on $40 \mathrm{HNSCC}$ patients, a significant decrease in overall survival was noted for patients carrying the XPD Gln751 allele (Farnebo et al. 2013). Unfortunately conflicting data exist in this subject, most likely reflecting the heterogeneity of the disease.

The X-ray repair cross-complementing group 1 (XRCC1) plays a role within the base excision repair (BER) pathway of DNA repair. After a single damaged base is removed from the DNA by base specific DNA glycosylase, XRCC1 stimulates endonuclease action and acts as a scaffold in the rebuilding of the damaged site (Vidal et al. 2001). An SNP within the $\mathrm{XRCC} 1$ gene has been associated with an increased risk of developing esophageal, lung and prostate cancers. As for XPD conflicting results are shown for the relation between SNPs in XRCC1 and HNSCC. A better response to cisplatin treatment has been linked to the XRCC1 Gln399Arg polymorphism in non-small-cell lung cancer (Giachino et al. 2007).

Lastly we included the X-ray repair cross-complementing group 3 (XRCC3) in this thesis. It takes part in the DNA double strand break (DSB) repair pathway. These kind of severe damages are common in radiation injuries to the DNA and are precarious since they can lead to genome rearrangements. XRCC3 takes part in the homologous recombination pathway of DSB. In these injuries the DNA ends are resected and the exposed 3' single strand tails invade a double helix of a homologous molecule allowing the DNA to be rebuilt via DNA polymerase. Yet again we find conflicting results when it comes to the association between the risk of developing HNSCC and the XRCC3 Thr241Met SNP. Interestingly enough there was a significant association between the XRCC3 Thr241Met polymorphism and the susceptibility to radiation in fibroblasts exposed to 2 Gy (Alsbeih et al. 2007).

\section{Src}

Src or c-Src is one of the nine members of the Src family of kinases. It is activated by EGFR and is implicated in at least two EGFR pathways; 1) signal transducer and activator of transcription (STAT) pathway and 2) Src/Focal adhesion kinase (FAK). Other EGFR pathways, such as PI3K, exhibit cross-activation via Src (Scaltriti \& Baselga 2006). Furthermore Src is also activated by several other mechanisms including receptor tyrosine kinases (including platelet-derived growth factor receptor (PDGFR), and IGF-1), cytokines, and integrins (Ishizawar \& Parsons 2004) to mention a few. This can result in Src activating 
EGFR pathways, such as PI3K and STAT, in a Src dependent manner following EGFR inhibition.

Src is activated in many cancers displaying high EGFR levels. It has a potentiating effect on EGFR by forming Src-pEGFR complexes (Maa et al. 1995; Tice et al. 1999). Activated Src has been associated with poorer HNSCC differentiation and lymph node spread (Mandal et al. 2008).

\section{Ki67}

$\mathrm{Ki} 67$ is a protein present in the nucleus of a cell in all active phases of the cell cycle. The absence of Ki67 from resting cells (G0) makes Ki67 a well accepted marker of proliferation. Surprisingly not much is known about the function of Ki67. It has been associated with rRNA expression and has been found to be present in resting (G0) cells using highly sensitive methods (Bullwinkel et al. 2006). Despite this it is still undetectable using standard paraffin embedded histopathological techniques and remains a marker of proliferating cells. A high expression of $\mathrm{Ki} 67$ has been correlated with poor survival and higher incidence of lymph node spread in HNSCC. HNSCC tumors having a worse prognosis such as hypopharyngeal cancers display an overexpression of Ki67 staining while laryngeal cancers which in general exhibit a favorable prognosis show the lowest Ki67 expression (Szentkúti et al. 2014).

\section{Human papilloma virus}

Human papilloma virus (HPV) has been implicated in more than two thirds of all oropharyngeal squamous cell carcinomas (D’Souza et al. 2007; Näsman et al. 2009). Tumors involving a tonsil or base of tongue are the most common HPV related tumors and they respond more favorable to RT than their HPV negative counterparts (Sedaghat et al. 2009). In contrast the HPV positive tumors have an earlier onset by about one decade.

The most common HPV type involved in carcinogenesis in HNSCC is type 16. Its carcinogenic effect is mediated by two oncogenes, E6 and E7 (Münger \& Howley 2002). E6 binds and forms complexes with p53 which results in p53 degradation (Werness et al. 1990) while E7 destabilizes the Rb tumor suppressor protein (Dyson et al. 1989). These two events result in faults in apoptosis, DNA repair, and cell cycle control thereby leading to malignant transformation. 


\section{KRAS}

KRAS is one of three members of the RAS family in humans. KRAS participates in the MAPK pathway and can also activate the PI3/Akt pathway. Mutations within the KRAS gene are common in colorectal cancers (CRC) resulting in a permanent activation of the KRAS protein. This activates the EGFR signaling pathway even when EGFR activity is inhibited. Hence tumors possessing the mutated KRAS gene are insensitive to cetuximab treatment (Yoon \& Kim 2014).

The KRAS mutation occurs in less then $5 \%$ of HNSCC and is thus not a useful predictive marker for cetuximab sensitivity. It was therefore not examined further in this thesis. 


\section{AIMS OF THE THESIS}

The overall aim of this thesis was to analyze proteins and genetic factors in order to assess their possible function as predictive markers for treatments such as cetuximab, cisplatin and radiotherapy within HNSCC.

More specific aims of the studies were:

1. To establish a model where several factors, both on the protein and the genetic level, could be combined in order to predict cisplatin response in HNSCC cell lines.

2. To investigate the intrinsic sensitivity to radiotherapy, cisplatin and cetuximab treatment, alone or in combination, of 25 HNSCC cell lines established in Linköping. Moreover, to analyze if the EGFR status and/or the expression of EGFR ligands could predict the treatment sensitivities.

3. To investigate further the functional importance of the EGFR ligands EGF, AREG, and EREG in relation to proliferation and cetuximab sensitivity.

4. To examine if the intrinsic sensitivity to cetuximab defined in vitro correlates to the in vivo sensitivity of xenografts. Furthermore, to search for differences in the EGFR pathway between sensitive and insensitive tumors that could predict the cetuximab treatment response. 


\section{MATERIAL AND METHODS}

\section{Cell lines from Turku University}

HNSCC cell lines used in papers I and IV were kindly provided by Professor Reidar Grenman at Turku University, Finland. All cell lines were cultured in Dulbecco's Modified Eagle's Medium supplemented with glutamine, non-essential amino acids, penicillin, streptomycin and fetal bovine serum. Cells were subcultured once a week and screened periodically for mycoplasma contamination. Cells in passages 10-25 were used.

Cell lines were established from HNSCC patients and full background is known concerning each cell line. Data includes date of birth, gender, tumor location, TNM, smoker vs nonsmoker etc. These cell lines bear the prefix UT-SCC-XX (where XX is the number of the cell line.)

\section{Cell lines from Linköping University}

HNSCC cell lines investigated in papers II, III and IV were all established from patients at the department of otorhinolaryngology and head and neck surgery, Linköping University Hospital. Patients participated voluntarily and with informed consent (approved by the Linköping University ethical committee). Established cell lines were grown in Keratinocyteserum free medium supplemented with penicillin, streptomycin and fetal bovine serum. Epithelial origin of the cell lines was verified by examination of the morphology by light microscopy and cytokeratin staining. Cells were subcultured once a week and screened periodically for mycoplasma contamination. Cells in passages 4-25 were used. Similar to the UT-SCC cell lines extensive data regarding the origin of the cell lines, which are all named with the prefix LK, is available. Furthermore we have access to medical charts allowing us to retrieve additional information associated with each cell line such as risk factors, clinical response to given therapies and survival rates.

\section{Radiotherapy, cisplatin and cetuximab treatments of HNSCC cell lines}

The intrinsic radiosensitivity (IR) of the UT-SCC cell lines was assessed in Turku as described before (Pekkola-Heino et al. 1995; Grenman et al. 1989). In Linköping the cells were irradiated with 2 Gy (IR; linear accelerator; Clinac 4/100), exposed to cisplatin $(1 \mu \mathrm{g} / \mathrm{ml})$ for 1 hour (ICS) or exposed to cetuximab (30 nM; ICmabS), alone or in combination. For the 
assessment of ICS, cells were in paper I exposed to cisplatin 24 hours after plating. In paper II the cells were given cisplatin at 48 hours instead, since some cells were pretreated with cetuximab for 24 hours in this experimental setup.

\section{Assessment of intrinsic treatment sensitivity}

In paper I tumor cells were seeded in 6 well plates at densities of $200-400$ cells $/ \mathrm{cm}^{2}$ depending on the plating efficiency of each cell line. Nine days after treatment cells were fixed in $4 \%$ paraformaldehyde (PFA), stained with $2 \%$ Giemsa and thereafter all colonies containing more than 32 cells were counted. In papers II, III and IV this time consuming method was replaced by the crystal violet assay. To perform this assay tumor cells were seeded in 12 well plates at densities of 300-800 cells $/ \mathrm{cm}^{2}$ depending on the plating efficiency of each cell line. The density was titrated for each cell line so that confluence was not reached within the experiment. Nine days after treatment cells were fixed in $4 \%$ PFA, stained with crystal violet, rinsed in tap water and afterwards solubilized in $1 \%$ sodium dodecyl sulphate (SDS). After solubilization the optical density at 550nm was measured using a Victor plate reader. In both cases a sensitivity ratio was then obtained by dividing the data received for the treated cells by the data from the controls.

\section{Quantitative polymerase chain reaction (qPCR)}

The polymerase chain reaction is a common method in amplifying small amounts of DNA to virtually pure target sequence. The method in short is based upon heating the DNA so that the two strands separate from each other. Specific primers are added that bind to the 3' end of the target sequence. Heat stable DNA polymerase then rebuilds the DNA strand towards the 5' end. This creates a copied partial double stranded DNA chain. This cycle is then repeated multiple times and the target sequence becomes exponentially amplified. In qPCR we are quantifying the amount of mRNA for specific proteins. The first step of the procedure is to synthesize a complementary DNA (cDNA) for our targeted mRNA. This is done via the help of a reverse transcriptase, an enzyme that synthesizes cDNA using RNA as a template. This process is called reverse transcription. In the next step, this target cDNA is amplified by PCR in the presence of a specific probe that binds our cDNA much like the primers. However the probe has two extra molecules covalently bound to it. At the 5'end there is a fluorophore molecule, in our case 6-carboxyfluorescein (FAM), which is able to absorb light and more importantly re-emit light at a longer wavelength. A quencher molecule is bound at the 3' end. 
Our probes used dihydrocyclopyrroloindole tripeptide minor groove binder (MGB). When being located in close proximity of the FAM molecule the quencher MGB absorbs any light given off by an excited FAM. However during the PCR process the heat stable DNA polymerase encounters the FAM/MGB probe and using its 5'-3' exonuclease activity breaks down the probe into individual nucleotides. In doing so the nucleotide bearing the FAM molecule is separated from the quenching MGB nucleotide thus allowing light emitted by FAM to be detected.

In order to make sure that any differences in the amount and/or quality of the RNA does not influence the results upon inter-sample comparisons, so-called housekeeping genes, such as GAPDH and $\beta$-actin, are used as internal standards. The level of expression of the internal standard must remain unaltered during treatments of the investigated cells. The comparative Ct method (Leutenegger et al. 1999) is used to calculate the fold-difference in the mRNA expression level relative to a calibrator sample.

qPCR was used in paper II for the determination of the expression level of EGFR and its ligands and in paper III in order to verify gene knockdown by RNA interference of EGFR ligands.

\section{RNA interference}

RNA interference is a method for specific gene silencing. This effect is achieved by delivery of a double stranded RNA molecule, usually about 20-25 nucleotides in length, into the cytoplasm of the cell. This short interfering RNA (siRNA) is then bound to a protein called argonaute. After unwinding of the double stranded RNA helix, one of the strands is degraded. The argonaute protein and the remaining RNA strand, called the guide strand, associates with other proteins to form the RNA-inducing silencing complex (RISC). RISC binds selectively to a complementary mRNA using the guide strand as a template. If a match is found the RISC complex then severs the targeted mRNA. This damaged mRNA is further degraded by exonucleases interrupting further translation of a specific gene.

This method was used in paper III in order to knockdown the expression of the EGFR ligands EGF, AR and EPR.

\section{DNA copy number}

DNA copy number refers to the number of copies of a particular gene within a cell. In paper II we investigated the copy number of the EGFR gene. FAM/MGB probes (applied 
Biosystems) were used for the PCR reaction. DNA was isolated from cell line cultures using a DNA isolation kit (Maxwell). USP34 and NUP37 genes were used as internal standards as they were found to remain in diploid state in all used cell lines.

\section{Enzyme linked immunosorbent assay (ELISA)}

ELISA is a quantitative technique used to determine the quantity of a specific protein in a sample. ELISA was used to measure various protein expressions in papers I-IV.

The total protein concentration of each sample was determined using the method described by Lowry et al (Lowry et al. 1951). The amount of each specific protein was examined using commercially available ELISA kits (R\&D Systems).

In brief, a capturing antibody, specific for the investigated protein, is added to each well of a 96-well plate. After over-night incubation non-specific binding sites are blocked using a blocking solution containing bovine serum albumin. This step covers any plastic surface that is uncoated by the antibody. Thereafter the cell lysate is added and after 2 hours this is followed by incubation with a specific detection antibody (linked with horse radish peroxidase; HRP), which also binds to the protein investigated. A substrate (tetramethylbenzidine) is added, and HRP catalyzes its conversion into a coloured product. A stop solution is added and the optical density at $450 \mathrm{~nm}$ is analyzed using a microplate reader. The amount of the specific protein is determined using a seven point standard curve and correlated to the total amount of protein.

\section{Number of negative points (NNP)}

Our group invented the NNP model in order to be able to combine several factors that potentially could influence the treatment outcome, such as protein expressions and SNPs, in a point system allowing us to correlate the sum to treatment sensitivities. This model was called number of negative points in the view that a positive score was adverse for the host or patient. In paper I we analyzed the expression of several proteins in HNSCC cell lines and compared it to the mean expression of each protein in normal oral keratinocytes (NOK). One point was awarded if a cancer cell line presented a 1.5 fold increase in the expression of a given protein as compared to NOK. Below 1.5 it received zero points. If the expression was increased by 4.5 fold or more the cell line was given 2 points, whereas 3 points were awarded above a 7.5 fold change. The point awarded could be either positive or negative depending on the function of that particular protein. An overexpression of a pro-apoptotic protein such as BAX, which is 
associated with improved treatment sensitivity and beneficial for a patient, would yield a negative score thus lowering the NNP sum. For presence of an investigated SNP a cell line was awarded one point. The total sum for a cell line was added up and compared to the known treatment sensitivities in an effort to find a correlation.

\section{Western blot analysis}

Western blot is a semi-quantitative method used in paper III in order to show the expression and phosphorylation status of EGFR before and after treatment with cetuximab. The method is based on the principle that differently sized molecules can move through a polyacrylamide gel, driven by an electric current, with different speeds. After the separation in the gel proteins are transferred to a nitrocellulose membrane. The membranes are incubated with specific antibodies against EGFR and phosphorylated EGFR, thereafter secondary antibodies coupled with a peroxidase are used for detection. Upon addition of a chemiluminescent substrate, the peroxidase (HRP) catalyzes a reaction in which light is produced in proportion to the amount of protein-bound primary antibody. This light is then recorded using photographic film or a digital camera.

To verify equal loading the membrane was reprobed with a HRP-conjugated anti-actin antibody. Densitometric analysis was performed for quantification.

\section{Immunofluorescence staining}

Immunofluorescence is a technique for detection of the expression and the distribution of specific antigens (proteins) using antibodies marked with a fluorophore. The most frequently used method is indirect immunofluorescence, in which the primary antibody directed against the protein of interest is un-marked while the secondary antibody carries the fluorophore. In the fluorescence microscope the fluorophore is excited by light of a specific wavelength and then emits light of a longer wavelength. The emitted light can be detected and the distribution of the specific antigen within a cell can thus be observed.

In paper III the distribution of EGFR was investigated using indirect immunofluorescence in three HNSCC cell lines. Furthermore changes in the distribution of EGFR were also examined after cetuximab treatment. 


\section{In vivo - xenograft model}

BALBc $(\mathrm{nu} / \mathrm{nu})$ mice were used in paper IV in order to study the properties of HNSCC solid tumors with different cetuximab sensitivity. A mutation within the FOXN1 gene of the nude mice results in inhibition of the mouse immune system and also a lack of body hair giving it its nude appearance. The disrupted FOXN1 gene causes athymia resulting in an absence of mature T cells (Romano et al. 2013). This impaired immune system therefore fails to reject xenografts making it possible to study HNSCC in solid tumors.

UT-SCC-14 and UT-SCC-45 tumor cells ( $5 \times 10^{6}$ cells/injection) were injected into both flanks of BALBc (nu/nu) mice. These cell lines were chosen because they have different sensitivities towards cetuximab and were known to form xenografts. The mice received intraperitoneal injections of cetuximab (1 mg/injection) or PBS on day 10, 13, and 16. Tumor volumes were measured every 2-3 days and the mice were sacrificed on day 19. These tumors were then excised and embedded in paraffin blocks.

\section{Tissue microarray (TMA)}

TMA allows us to study several tissue specimens on one histological slide. In short, the tumors were after fixation embedded in paraffin blocks and from each tumor block two $1 \mathrm{~mm}$ diameter cores were taken and arranged in an array format in a recipient TMA block. Sections of this block was cut using a microtome and mounted on a microscopic slide.

In paper IV we study the localization and staining intensity of a panel of proteins using the TMA from HNSCC xenografts and immunohistochemistry.

\section{Immunohistochemistry (IHC)}

IHC is a method of staining for specific proteins or other antigens on tissue sections using antibodies. The most common method to use is indirect IHC where a primary antibody binds the antigen investigated and the secondary antibody binds to the FC segment of the primary antibody. The secondary antibody can either be conjugated to a tracer enzyme such as HRP or to a biotin molecule. The conjugated biotin molecule does not directly function as a tracer enzyme but rather as an anchor point for avidin. Avidin and biotin bind at a high affinity and each secondary antibody-biotin-avidin complex can bind another 3 biotin molecules (avidin has four binding sites for biotin). Since 3 of these tracer biotin molecules bind each secondary antibody we get an amplification of the tracer signal. HRP catalyzes a reaction where 3,3'diaminobenzidine (DAB) and $\mathrm{H}_{2} \mathrm{O}_{2}$ causes a brown precipitate and $\mathrm{O}_{2}$. After a 
counterstaining of the tissue sections with hematoxylin the localization and intensity of investigated proteins can now be visualized using light microscopy.

IHC was used in detecting EGFR, pEGFR, pSrc, and Ki67 in paper IV. The staining patterns were scored blinded without the knowledge of cell line or treatment by 3 investigators. EGFR, pEGFR, and pSrc were predominantly membranous and were scored according to the percentage of positively stained cells and cell staining intensity. Ki67 staining was nuclear and scored accordingly to the percentage of stained cells.

\section{Restriction fragment length polymorphism (RFLP)}

RFLP is a genetic analysis used in DNA profiling. It is based on the use of restriction enzymes that cut the PCR amplified DNA in specific regions resulting in unique DNA fragments. The fragments are separated by gel electrophoresis depending on the length of the fragment. If the DNA is not cut in the specific region a mutation is present at the site that protects the DNA from the nuclease activity.

RFLP was used to investigate SNPs in the genes for p53, FGFR4, XPC, XPD, XRCC1, and XRCC3 in paper I.

\section{Pyrosequencing of MDM2}

In paper I the SNPs in the MDM2 gene were investigated using pyrosequencing. A single stranded DNA for the MDM2 gene is obtained after PCR reaction. This single stranded DNA is then annealed with a primer for the MDM2 gene. Nucleotides are then added in a predetermined order. A DNA polymerase then adds the nucleotide and the pyrophosphate that was released initiates a reaction where a luciferase-driven light is emitted. The intensity of the light is proportionate to the amount of nucleotides added. If a point mutation is encountered, the planned nucleotide added will not be complementary and no light will be emitted.

\section{Statistical methods}

In paper I, Pearson's correlation test was used to calculate the correlation between ICS and the different predictive markers, and the correlation between the NNP score of the predictive markers and ICS. Mann-Whitney U-test was used to analyze the significance of SNPs for cisplatin sensitivity. Furthermore a multivariate statistical calculation was performed to identify the combination of factors (both protein and SNPs, using the NNP system) with the strongest correlation to ICS. 
In paper II, Pearson's correlation test was used to analyze the correlation between all the single factors and IR, ICS, and ICmabS. The Mann-Whitney U-test was used to analyze the differences in EGFR status (copy no, mRNA level, and protein expression), pEGFR, and pAkt between the 6 most sensitive and 6 most resistant cell lines to RT, cisplatin, and cetuximab.

In paper III, one-way ANOVA followed by t-tests with the Bonferroni adjustment were used to calculate the differences between the groups studied.

In paper IV, the Mann-Whitney U-test was used to calculate the differences within IHC staining patterns of the cetuximab treated and untreated xenografts. 


\section{RESULTS AND DISCUSSION}

\section{Paper I}

The aim in paper I was to assess the possibility to use a point scoring system in order to combine both a panel of proteins and SNPs involved in apoptosis, growth control, and DNArepair as predictive markers for cisplatin response.

Cisplatin is a platinum based chemotherapeutic drug most often given in combination with RT. It is the most effective chemotherapeutic substance within HNSCC however it does cause severe neuro-, nephro- and ototoxic side effects. It is estimated that only about $25 \%$ of HNSCC patients receiving cisplatin actually benefit from the treatment leaving the remaining $75 \%$ only to suffer from the side effects. The prediction of cisplatin sensitivity of a given HNSCC tumor would allow us to customize and adapt treatment regimes.

ICS was investigated in 39 HNSCC cell lines using surviving fractions of the cells as compared to their untreated control. The values varied from 0.00 to 1.00 , with a median of 0.52. Furthermore the IR was known for these 39 cell lines due to previous investigations done by our colleagues in Åbo. The survival data was fitted as a function of the radiation dose using a linear quadratic equation. The area under the curve (AUC) was obtained by numerical integration and varied between 1.4 and 2.6 with a median of 2.0. Our lab does not employ this method for assessment of the radiosensitivity however the data was used in order to correlate the IR to the ICS for these cell lines. It has previously been hypothesized clinically that patients sensitive towards RT would also be sensitive towards chemotherapy. No such correlation could be found using Pearson's correlation analysis in our cell lines. In fact they showed complete variation in their cisplatin and radiation sensitivities.

The expression of EGFR, Hsp70, Bax, Bcl-2, Bcl-Xl, survivin, and Cox-2 was determined using ELISA and correlated to cisplatin response. Only the EGFR expression had a statistically significant correlation to the cisplatin sensitivity $(r=0.388, P=0.015)$. The conversion of the overexpression for the measured proteins into points within the NNP system allowed us to generate various NNP scores based on the combination of different factors and to correlate the scores to the ICS. The combination of EGFR, Hsp70, Bax, and Bcl-2 yielded the strongest correlation to ICS among the proteins $(r=0.566, p<0.001)$.

Since cisplatin forms DNA-adducts in treated cells we hypothesized that SNPs within DNArepair genes could alter the cellular response to this chemotherapeutic agent. Therefore the correlation between ICS and SNPs in four DNA-repair genes (XRCC1 Gln399Arg, XRCC3 
Thr241Met, XPC Ala499Val, and XPD Lys751Gln) was investigated. All four SNPs had a tendency of lowering the median ICS for the group that had at least one variant allele as compared to the homozygous wild-type. This difference between the groups did not however reach a significant level when evaluated by the Mann-Whitney U test. Furthermore, the cell lines bearing the FGFR $4{ }^{388} \mathrm{SNP}$ tended to be more sensitive to cisplatin, however no statistical significance could be found. The SNPs for the tumor suppressor protein p53 Arg72Pro and $M D M 2^{309}$ did not have any impact on the ICS. Interestingly, an increase in the correlation was found when incorporating the $\mathrm{XRCC}^{241}$ and $\mathrm{XPD}^{751}$ polymorphism into our panel of proteins using the NNP system. The strongest correlation was found using the following combination; EGFR, Hsp70, Bax, Bcl-2, XRCC3 ${ }^{241}$, and $\mathrm{XPD}^{751}(\mathrm{r}=0.614, \mathrm{p}<0.001)$. This was first extracted using Pearson's correlation test and verified by a multivariate analysis.

A possible shortcoming of the NNP method is that the factors are not weighted and all are assumed to be of equal importance. Since a single genetic variation or the overexpression of a single protein most likely will not be able to predict the sensitivity towards cisplatin it is challenging to add weight to the different factors. Since EGFR was the only factor that by itself had a significant correlation towards ICS, further evaluation of its role was relevant.

4 cell lines were selected, each with a varying expression of EGFR (in increasing order UTSCC-12A, UT-SCC-9, UT-SCC-2 and UT-SCC 24A). It is worth noting that although the cell lines had varying expression of EGFR only UT-SCC-12A was sensitive towards cisplatin treatment. The cell lines were then treated with the monoclonal anti-EGFR antibody, cetuximab, alone or in combination with cisplatin. This setup allowed us to further evaluate the impact of EGFR on the ICS. The anti-EGFR antibody itself had cytotoxic/cytostatic effects in UT-SCC-9 and UT-SCC-24A. These cell lines had a 4- and 19-fold overexpression of EGFR as compared to normal oral keratinocytes. In contrast the least overexpressing EGFR cell line, UT-SCC-12A (with an EGFR expression almost at the level of normal oral keratinocytes) and the 12-fold overexpressing UT-SCC-2 did not respond to cetuximab treatment. No synergistic effect was observed upon treatment with cisplatin and cetuximab although an additive effect could be noted in UT-SCC-9. It became clear that EGFR is not an adequate predictive marker of cisplatin sensitivity. A clear relationship between the amount of EGFR overexpression and ICmabS was not noted prompting us to investigate the sensitivity of cell lines to cetuximab treatment in future work.

Following EGFR, Hsp70 and Bax were the two proteins with the highest influence on the correlation to ICS. Interestingly, Hsp70 overexpressing cells have been shown to respond poorly to both chemo-radiotherapy and RT (Miyazaki et al. 2005). 
Paper I was our attempt to combine several factors into a system that could predict the ICS. Although reaching a significant correlation it was clear that further effort must be placed on the identification of new predictive markers. Furthermore the function of EGFR was not straightforward and further evaluation of the EGFR pathway and EGFR inhibition via cetuximab was warranted. 


\section{Paper II}

The aim of paper II was to investigate further the EGFR status and the expression of EGFR ligands in relation to sensitivities to RT, cisplatin and cetuximab treatments and their combinations in LK HNSCC cell lines.

Our laboratory established $25 \mathrm{HNSCC}$ cell lines from biopsies taken from patients at the Department of Otorhinolaryngology and Head and Neck Surgery at Linköping University Hospital. 11 cell lines were established from the tongue, 7 from the gingiva, 5 from the larynx, one from the base of tongue, and one from the maxillary sinus. Interestingly we have not managed to establish a cell line derived from tonsil cancer.

The 25 cell lines were tested for their intrinsic treatment sensitivities towards cisplatin, radiation, and cetuximab. Furthermore the combination of these treatments was also examined. It was noted that no correlation could be found between IR, ICS, and ICmabS thereby supporting the results of paper I. This finding also implicate that different factors within the cancer cells seem to determine the response to each treatment.

The median SF for ICS was 0.90 (ranging from 0.66 to 1.08), although the median for IR was 0.70 (ranging from 0.48 to 0.89 ) and the lowest median SF for ICmabS was 0.58 (ranging from 0.20 to 1.25 ). Alarmingly, the LK0855 cell line essentially proliferated after addition of cetuximab as compared to its cetuximab untreated control.

After paper I we noticed the hitherto unclear role of EGFR within HNSCC. In this previous work we found a weak correlation between EGFR and ICS $(\mathrm{r}=0.388, \mathrm{P}=0.015)$. Building further on these findings we investigated in our newly established LK cell lines the EGFR status, which comprised not only of the amount of EGFR protein but also gene copy number, mRNA expression, and phosphorylation status, as well as the phosphorylation status of the downstream effector Akt. No correlation was found between treatment sensitivities and the EGFR status within these 25 cell lines. A weak correlation between EGFR expression and ICS was found in paper I. We suspected that EGFR is not a strong predictive marker and paper II confirms this notion further. Additional reason for our loss in correlation between EGFR and ICS could be the tumor heterogeneity that HNSCC displays. Most likely the combination of these two assumptions reflects reality in tumor biology.

There was a significant correlation between EGFR gene copy number and EGFR mRNA ( $\mathrm{r}=$ $0.499, \mathrm{P}=0.011)$ and between EGFR gene copy number and EGFR protein expression $(\mathrm{r}=$ $0.615, \mathrm{P}=0.001)$. Furthermore literature reports an overexpression of EGFR in $38-80 \%$ of investigated tumors (Grandis \& Tweardy 1993; Ongkeko et al. 2005; Bei et al. 2004). We 
noted an overexpression of EGFR mRNA and protein (1.5 fold expression was categorized as an overexpression as compared to NOK) in 48 percent of our cell lines.

The mRNA of the 7 known EGFR ligands (EGF, AREG, EREG, TGF $\alpha$, EPGN, BTC, HBEGF) was also investigated in our 25 cell lines. Here we noticed that TGF $\alpha$ and AREG was not overexpressed as compared to NOK, while EGF and BTC was generally overexpressed (at least a two-fold increase in $76 \%$ and $84 \%$ of the cell lines, respectively). Unexpectedly, a weak but significant correlation was found between EREG and ICmabS $(r=0.408, P=$ $0.043)$.

In order to evaluate the EGFR status and EGFR ligands further and to bypass tumor heterogeneity we looked at the six most sensitive and six most resistant cell lines for each treatment and compared them statistically using Mann-Whitney U-test. The most important findings are summarized below:

$\underline{\text { Radiotherapy resistance }}$

- $\quad$ High pEGFR $(\mathrm{P}=0.09)$

- $\quad \operatorname{High} \operatorname{EREG}(\mathrm{P}=0.18)$

- $\quad$ Low EPGN $(\mathrm{P}=0.13)$
Cetuximab resistance

- Low pEGFR $(\mathrm{P}=0.13)$

- Low pAkt $(\mathrm{P}=0.31)$

- Low EREG $(\mathrm{P}=0.18)$
Cisplatin resistance

- $\quad$ Low EGFR $(\mathrm{P}=0.04)$

- $\quad$ Low pAkt $(\mathrm{P}=0.13)$

- $\quad$ Low AREG $(\mathrm{P}=0.18)$

Although statistical significance between the sensitive and resistant cell lines was only found for ICS and the level of EGFR protein $(\mathrm{P}=0.04)$ clear tendencies are seen in the figures showing the median values (paper II figs. 2-5).

Worth mentioning here is the contradiction between paper I and II concerning EGFR and ICS. In paper I we showed that EGFR was the only protein that alone correlated to ICS and the slope of the curve indicates that low EGFR implies cisplatin sensitivity. Here however we have the opposite indication, i.e., that a low level of EGFR is associated with cisplatin resistance. There are differences in the experimental setup between the two papers, such as different times that the cell lines were exposed to cisplatin, different types of cell culture medium and different methods for detection of the clonogenic survival. These differences could account for these opposing results. Furthermore it is important to remember that in paper I the statistical significance was weak $(r=0.388, P=0.015)$. If we square the value of $r$ we get 0.15 which means that $15 \%$ of our data conforms our significance. That means that 5,8 of our cell lines attribute to our correlation. If we look at fig. $1 \mathrm{~A}$ in paper I we can see that the points on the graph could as well be represented by a line sloping the opposite way. So the opposing results are more likely due to a weak correlation than differences in 
laboratory setup. An idea would be to combine the cell lines from paper I and II and examine the influence of EGFR on the treatment sensitivities in all of them, and also to compare the EGFR expression in the most sensitive and resistant cell lines.

The question remains as to how we could tailor treatments for individual HNSCC patients. Activating KRAS mutations are associated with cetuximab resistance in colorectal cancer patients and is present in 30-40 \% of all tumors. Within HNSCC KRAS mutations are much less frequent $(<5 \%)$ and thus not a useful predictive marker. EGFR variant III, which lacks the extracellular ligand-binding domain and is constitutively active, is the most common altered form of EGFR in HNSCC (up to $40 \%$ ). It is associated with increased proliferation, tumor growth and resistance to antitumor drugs such as cetuximab (Sok et al. 2006). However the EGFR variant III is not found in tumor cell lines (Lammering, Hewit, et al. 2004; Lammering, Valerie, et al. 2004) and was therefore not considered here.

Distressingly enough, one of the cell lines, LK0855, proliferated after treatment with cetuximab. This suggests that some HNSCC patients could have serious adverse effects if treated with cetuximab. LK0855 had the lowest EGFR gene copy number, lowest EGFR mRNA, and lowest EGFR protein level. Even the activated forms of EGFR and Akt were low, about $25 \%$ below the level of NOK. It is hard to evaluate these findings since we have only one cell line that has such low levels of EGFR. It is however clear that the function and role of EGFR is very intricate and complex and perhaps some form escape mechanism exists in LK0855 allowing it to proliferate. 


\section{Paper III}

Due to its elevated level in HNSCC EGFR is, in theory, a very promising candidate for targeted therapy. The monoclonal antibody cetuximab is specifically directed towards the EGFR. Furthermore it is the only targeted therapy available for patients suffering from late stage HNSCC. Despite this only about $20 \%$ of patients receiving cetuximab actually show disease stabilization and prolonged survival. Alarmingly, we have seen in paper II that the HNSCC cell line LK0855 actually proliferates after cetuximab treatment. The consequences of such proliferation could be catastrophic in the clinical setting. A clear need for predictive markers of treatment response in HNSCC are needed however none exist to this date. An increased knowledge about the EGFR and its pathway is needed for such a predictive marker of cetuximab treatment efficacy to be discovered. The aim of paper III was to investigate the functional importance of the EGFR activating ligands EGF, AREG, and EREG in relation to proliferation and cetuximab sensitivity in three tongue cancer cell lines.

After paper II it was clear that the tumor heterogeneity displayed by HNSCC is a challenge in the attempt to assess the mechanisms underlying treatment resistance. In an effort to reduce the influence of tumor heterogeneity we selected three cell lines, LK0412, LK0824, and LK0902, that differed in their ICmabS but were derived from the same anatomical region. These cell lines originate from T1-T2 tumors of the mobile part of the tongue. Both LK0412 and LK0902 are T1N0M0 early stage tumors while LK0824 was classified as T2N1M0, i.e., a late stage tumor. The histological grade for LK0412 was moderately differentiated while LK0824 and LK0902 were well differentiated. Furthermore the EGFR status and the mRNA expression of the EGFR ligands were known from paper II (Table 2, paper III).

The effect on proliferation by stimulation of EGFR was first evaluated by adding recombinant EGF. In LK0902 cells there was a significant increase in proliferation while the remaining cell lines showed a slight anti-proliferative effect. Interestingly, LK0902 was the cell line expressing the lowest amount of EGFR, comparable to the level of NOKs (Table 1). 


\begin{tabular}{lccc} 
& LK0412 & LK0824 & LK0902 \\
\hline ICmabS & 0.79 & 0.49 & 0.42 \\
EGFR status & & & \\
mRNA & 1.7 & 1.5 & 0.4 \\
protein & 5.3 & 2.3 & 0.8 \\
pEGFR & 4.7 & 1.8 & 1.1 \\
& & & \\
Proliferation & & - & ++ \\
rhEGF & - & $-*$ & $+*$ \\
rhAREG & $-*$ & - & $+*$ \\
rhEREG & - & -- & - \\
& -- & -- & --- \\
siRNA EGF & - & $\Delta 0$ & $\Delta 0$ \\
siRNA AREG & $\Delta 0$ & & \\
siRNA EREG & - & &
\end{tabular}

Table 1. Summary of EGFR status and effect of ligand stimulation and suppression EGFR status is shown as fold difference as compared to NOK. * Denotes differences with that did not reach the level of significance. $\Delta 0$ Denotes no change found.

+ increase in proliferation. - decrease in proliferation.

Despite the fact that LK0412 and LK0824 are having a 5- and 2-fold overexpression of EGFR addition of EGF did not stimulate proliferation, but rather the opposite effect was achieved. Briefly, a similar effect was seen upon both rhAREG and rhEREG treatment. Please note that the level of significance was not reached for changes induced by rhAREG treatment in any of the cell lines even though a clear trend was visible (Fig. 1B, paper III). Similarly the level of significance was not reached for the changes observed upon addition of rhEREG in cell line LK0902 despite an obvious trend (Fig. 1C, paper III).

After downregulation of the endogenous production of EGF and AREG with siRNA an inhibition of proliferation was observed. This effect could not be achieved after downregulation of EREG. This EGFR expression-dependent pattern of response to ligands has been previously described (Modjtahedi et al. 1993; O-charoenrat et al. 2000). Earlier studies suggested that cell lines with high EGFR expression are sensitive to very low ligand 
concentrations while growth inhibition occurs at higher concentrations (Modjtahedi et al. 1993). We therefore propose in paper III based on these findings that the level of EGF under basal conditions was within the concentration range optimal for growth stimulation for all three cell lines. In LK0902, the concentration of EGF remained growth stimulatory also after addition of rhEGF. On the other hand, in the two EGFR overexpressing cell lines the level of EGF after the addition of recombinant protein reached a supra-optimal concentration, at which the cells proliferated at a rate lower than that of the untreated controls.

Another very interesting aspect of paper III is demonstrated in Fig. 3A and B (paper III) where we investigate the changes in ICmabS while treating the cell lines with rhEGF or siRNA EGF. In all three cell lines a significant resistance towards cetuximab is induced by rhEGF. Furthermore a downregulation in endogenous EGF production mediates a significant increase in cetuximab sensitivity in LK0824 while the remaining two cell lines show a similar change though not at the level of significance. In our work we show that EGF expression is functionally associated with resistance to EGFR-targeted therapy.

Interestingly, studies done within colorectal cancer relate high EGFR ligand expression with good treatment response to cetuximab. Our study contrasts this and is further supported by work done by Hatakeyama et al where they provoke cetuximab resistance in HNSCC cell lines by inducing HB-EGF overexpression (Hatakeyama et al. 2010).

AREG and EREG have gained some status as biomarkers for cetuximab response in KRAS wild-type colorectal cancers (Jacobs et al. 2009; Khambata-Ford et al. 2007; Saridaki et al. 2011) and conflicting data exists for the expression level of AREG and cetuximab treatment outcome in colorectal cancers versus HNSCC. In our study with the three tongue cancer cell lines erratic data was found when examining the rhAREG addition and AREG silencing.

To further investigate the mechanisms behind the differences in cetuximab sensitivity we analyzed the levels of EGFR and pEGFR in the three cell lines before and after treatment with EGF and/or cetuximab (Fig. 4, paper III). Two major observations were made: Firstly the level of EGFR was lowered after cetuximab treatment in the most cetuximab sensitive cell line LK0902 while being elevated in the most resistant cell line, LK0412. Moreover, we noted that LK0824 whose sensitivity to cetuximab is closer to that of LK0902 showed a moderate decrease in EGFR. Secondly a similar pattern was observed for the activated EGFR levels after cetuximab treatment where the most sensitive cell line (LK0902) had the biggest decrease in the level of pEGFR and LK0412, being the most cetuximab resistant cell line, showed almost no change in pEGFR levels. In concordance with the observations for EGFR, LK0824 had a moderate decrease of pEGFR levels after cetuximab treatment. 
These results are only based on three HNSCC cell lines and further verification in a larger population is required. 


\section{Paper IV}

It has been a long-standing goal of our research group to find some form of predictive marker for treatment response that could be taken or measured directly from the patient. This has raised the question of reproducibility of in vitro studies in the in vivo setting. It is well know that the tumor microenvironment influences the cancer cells to progression, survival and metastasis, influences that our cell lines for apparent reasons are not exposed to. Previously we have tried to study the influence of the tumor microenvironment on the treatment sensitivity using co-cultures with cancer associated fibroblasts. Here we chose to try and reproduce our cetuximab sensitivities in xenografts in mice and compare these to ICmabS received from standard cell line cultures. Additionally we wanted to investigate differences in the EGFR pathway between cetuximab-sensitive and resistant tumors in order to further pursue the goal of finding predictive markers for cetuximab treatment response.

Two cell lines were selected based on their ICmabS and their ability to form solid tumors in mice. UT-SCC-14, which is derived from HNSCC of the mobile portion of the tongue, has a high sensitivity towards cetuximab treatment and a high expression of EGFR and pEGFR. The other cell line called UT-SCC-45 is resistant to cetuximab treatment and has a low expression of both EGFR and pEGFR. Interestingly the data regarding the expression of pEGFR of these cell lines was in agreement with results in paper II where cetuximab resistant cell lines had a tendency to express lower levels of pEGFR.

Apart from looking at the EGFR and pEGFR expression with IHC we also wanted to investigate pSrc since active phosphorylated Src has been linked to poor tumor differentiation and lymph node metastasis within HNSCC (Mandal et al. 2008) and has been reported to be overexpressed in breast, colon, and head and neck cancer. Src takes part in at least three of the downstream EGFR pathways (PI3K/Akt, STAT, and FAK). Furthermore the proliferation marker Ki67 was also studied since increased Ki67 expression has been linked to poorer prognosis in HNSCC tumors (Szentkúti et al. 2014).

The in vivo ICmabS of UT-SCC-14 and UT-SCC-45 in xenografts was determined by measuring tumor volumes at day 19 of the cetuximab treated and untreated mice. In analogy with the calculation of the surviving fraction in cell lines a ratio was then obtained by dividing the cetuximab treated volumes by the untreated controls. Data is presented in Table 2. 


$\begin{array}{lcc}\text { Cell line } & \text { In vitro } & \text { In vivo } \\ \text { UT-SCC-14 } & 0.14 & 0.22 \\ \text { UT-SCC-45 } & 0.73 & 0.83\end{array}$

Tabl. 2 ICmabS measured in cell lines and in xenografts. Values are presented as a ratio of cetuximab untreated controls.

A strong correlation was found between in vitro and in vivo data. It is however noteworthy that in vivo ICmabS values are slightly higher meaning that the cells are slightly less sensitive. The tumor stromal cells supporting the cancer cells and increasing their survival may cause this difference. It may also be due to an increased cell-cell contact, or an increased hypoxic environment. These results indicate that 2-D cell culture is a reliable research model for tumor cell drug sensitivity tests.

When looking at the results of IHC an interesting pattern emerges when observing EGFR and pEGFR and changes within the xenografts after cetuximab treatment (Fig. 3, paper IV). In UT-SCC-14, which is the cetuximab sensitive cell line, a significant lowering of EGFR and pEGFR staining was found, while in the cetuximab resistant UT-SCC-45 the opposite situation occurs. This was in line with the findings from paper III where western blot analysis revealed a decrease in EGFR and pEGFR levels after cetuximab treatment in LK0902, which is a cetuximab sensitive cell line. In the cetuximab resistant cell line LK0412 we could observe an increase in EGFR and pEGFR levels (Fig. 4, paper III). Thus, in two sets of cell lines (both in vivo and in vitro) our results show a similar pattern using different detection methods. To further verify these results another $8 \mathrm{HNSCC}$ cell lines (4 sensitive and 4 resistant to cetuximab) were investigated. In these cell lines the expression of pEGFR was analyzed after 4 days of cetuximab treatment $(60 \mathrm{nM})$ using ELISA. Our preliminary results show that all investigated cetuximab sensitive cell lines have a decrease in pEGFR levels and that all the resistant cell lines show an increase in pEGFR (Fig. 1). These data need to be verified and the change in the levels of EGFR after cetuximab treatment has to be analyzed as well. However, using a third method and an expanded panel of cell lines we have confirmed our findings. 


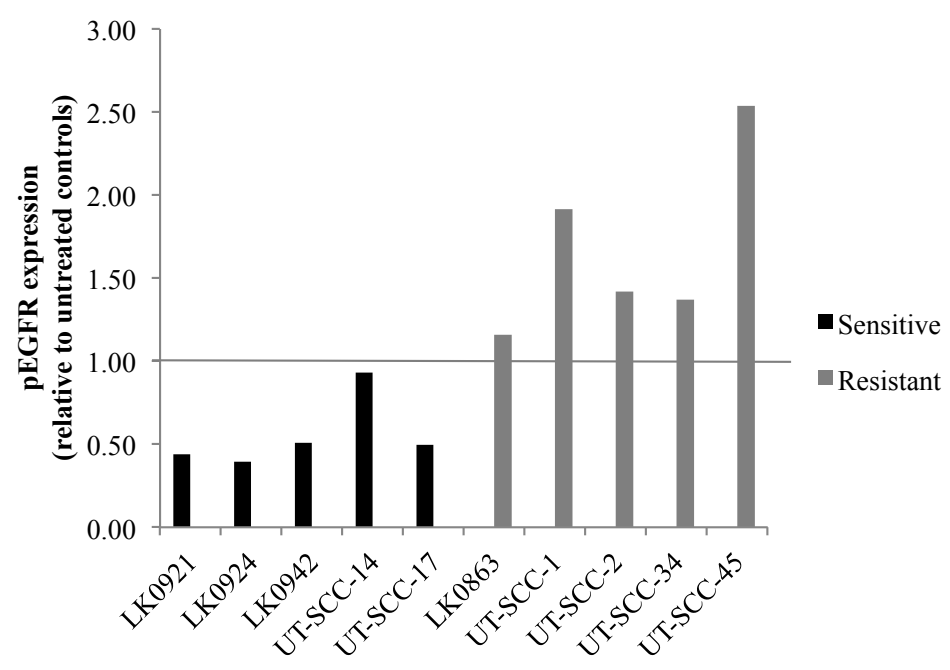

Fig. 1 Change in pEGFR level after 4 days of cetuximab treatment.

ELISA values are presented as a ratio of untreated controls in $10 \mathrm{HNSCC}$ cell lines.

Figure 4, in paper IV, shows a significant drop in both pSrc and Ki67 staining in UT-SCC-14 after cetuximab treatment whereas UT-SCC-45 xenografts tended to have an increased level of pSrc (not reaching the level of significance) and no change in the Ki67 staining. An elevated level of active Src family kinases has previously been associated with acquired cetuximab resistance (Wheeler et al. 2009). This could mean that the slightly elevated levels of pSrc in UT-SCC-45 after cetuximab treatment could compose a resistance mechanism. Interestingly, cetuximab resistance has been associated with translocation of EGFR to the nucleus (Li et al. 2009), and Src family kinases are known to mediate cetuximab-induced nuclear translocation of EGFR in HNSCC cell lines. However, we did not observe any increase in nuclear EGFR in cetuximab-treated xenografts, suggesting an alternative mechanism.

In UT-SCC-14 xenografts, that have a high level of EGFR expression, a clearly diminished staining pattern of the proliferation marker Ki67 after cetuximab treatment was noticed. Taken into consideration that the UT-SCC-45 cell line is much less growth inhibited in the presence of cetuximab and that the level of EGFR is low, we expected a decrease in Ki67 staining, although less pronounced as compared to in UT-SCC-14, however, this was not observed. It may be that the method of detection of staining is too crude to pick up a perhaps small reduction in Ki67 staining. We and other researches have noticed that tumors 
possessing low amounts of EGFR are more potently stimulated by the EGFR ligands (Ekblad et al. 2014; Modjtahedi et al. 1993). This possible scenario may explain the high degree of Ki67 staining in UT-SCC-45 under baseline conditions.

In summary we successfully demonstrated the reproducibility of the in vitro ICmabS in an in vivo setup. Moreover, a promising pattern has started to emerge in the intricate and complicated EGFR signaling pathway, as we were able to associate cetuximab sensitivity with treatment-induced reduction in EGFR, pEGFR and pSrc. 


\section{GENERAL DISCUSSION}

HNSCC is a very heterogeneous disease where two patients with similar stage, grade, and anatomical site of the cancer can react very different to the same treatment regime. In such a scenario certain plasticity in choice of treatment would be desirable in order to give the patients a treatment that the tumor is sensitive to. Researchers worldwide pursue the search for predictive markers to treatment sensitivities within HNSCC, however no results have so far been transferred into clinical practice. A single factor is not likely to reliably predict treatment response in HNSCC. Therefore, in paper I we combined proteins and genetic factors using a point system by which treatment sensitivities could be predicted. The search for a whole panel of proteins and genetic factors in itself is an enormous endeavor. The potential markers that we chose to investigate in paper I did not correlate very strongly to cisplatin treatment sensitivity.

Paper II was an important step for our laboratory, as it comprises multiple newly established cell lines derived from biopsies taken from HNSCC patients in Linköping. Cell lines constitute the foundation of basic research in tumor biology. They constitute an endless supply of material for in vitro studies, and the detailed data available concerning the patients from whom these cell lines were derived is a valuable asset. It is clear that some form of selection occurs during the establishment of a cell line since not all biopsies can spawn cell lines in our lab. For example, we have yet to this day not managed to establish a cell from a tonsil biopsy.

Paper II was further planned as primarily a mechanistic study of HNSCC cell lines and their expression rates of EGFR on genetic and protein level. Moreover the treatment sensitivities towards cisplatin, cetuximab, and RT were analyzed. No correlation between the different treatment sensitivities was found meaning that a specific cell line that is sensitive towards one treatment is not automatically sensitive towards another. Additionally a great variation was found in the treatment sensitivities among our 25 cell lines. As suspected in paper I we could not find a predictive marker among the investigated EGFR status and EGFR ligands that could solitarily predict treatment sensitivity. This is probably caused by the pronounced heterogeneity that HNSCC features requiring most likely a panel of markers in order to successfully foresee the treatment outcome.

Paper III was set up to be a functional study of the EGFR pathway and cetuximab treatment. Three cell lines were selected that originated anatomically from the same region but had 
different sensitivities towards cetuximab treatment. We stimulated the EGFR receptor by addition of recombinant ligands, or reduced EGFR activation by lowering of the level of endogenous ligand, and studied the influence on the response to cetuximab, a treatment form directed towards the EGF receptor. We concluded that 1) EGF strongly influences the tumor cell proliferation and the response to cetuximab treatment and 2) the expression of pEGFR decreases in cetuximab sensitive cell lines. These findings are however based on 3 cell lines and thus need to be further verified.

Shirasuna et al. studied the distribution of EGF via IHC in HNSCC. The epithelial cells contained very little EGF staining while a substantial amount was found in the stromal compartment (Shirasuna et al. 1991). This of course strongly questions the use of 2D cell line cultures since we lack a potential source of EGF that we suspect influences both the tumor cell proliferation and the cetuximab sensitivity. Paper IV was set up in order to try and verify our data with more real life settings for cancer cells using xenografts grown in mice. Two cell lines were selected based on their sensitivity towards cetuximab and ability to form xenografts in mice. The aim was to see if ICmabS measured in cell lines could be reflected in xenografts and also follow the expression pattern of EGFR and pEGFR among others. The values for ICmabS in cell lines is a ratio of the amount of cells in the treated culture divided by the amount of cells in the controls. Within the xenografts we measure the volume of the whole tumor and also obtain a ratio when dividing by the untreated control tumor volumes. The in vitro and in vivo results from these two cell lines were very similar, however the values for the xenografts were slightly higher than those of the cell lines (Table 2). This could be the result of the tumor stroma supporting the cancer cells via mechanisms like EGF secretion. Furthermore we could see a drop in the level of pEGFR in the cetuximab sensitive cell line (UT-SCC-14) and an increase in the resistant cell line (UT-SCC-45). Since this pattern of pEGFR level change after cetuximab treatment was already noticed in paper III we decided to verify these results in 8 additional HNSCC cell lines. The preliminary data show a drop in pEGFR levels in all cetuximab sensitive cell lines and the opposite for all resistant cell lines (Fig. 1).

My interest in EGFR is based on the fact that in clinical work cetuximab treatment is reserved for the late stage advanced disease HNSCC patients. This is mainly based on the financial aspect since cetuximab is so far an expensive form of treatment. Finding a marker for cetuximab sensitivity could motivate cetuximab enhanced treatments of early as well as late stage tumors after a sensitivity screening. 


\section{CONCLUSIONS}

- The NNP system is a valuable tool for evaluation of combinations of biomarkers for the prediction of the response to a treatment. The combination of EGFR, Hsp70, Bax, Bcl-2, and the SNPs in XRCC3 and XPD within the NNP system could predict cisplatin sensitivity of HNSCC cell lines $(r=0.614, \mathrm{P} \leq 0.001)$.

- Sensitivities towards radiation, cisplatin, and cetuximab vary immensely between HNSCC cell lines. Furthermore, the treatment sensitivities (RT, ICS, and ICmabS) did not correlate to each other.

- EGFR expression level by itself does not correlate to treatment sensitivity towards cisplatin, cetuximab or radiotherapy.

- EGF is a potential predictive biomarker of poor cetuximab response and a possible treatment target. AREG and EREG showed no promising features to predict treatment sensitivity.

- Cetuximab sensitivity in vitro closely reflected the in vivo results found in xenografts indicating that $2 \mathrm{D}$ cell culture is a reliable research model.

- High sensitivity towards cetuximab treatment seems to be associated with treatmentinduced reduction in EGFR, pEGFR, and pSrc. 


\section{FUTURE}

Paper IV shows a decrease in pEGFR in xenografts sensitive to cetuximab after treatment with cetuximab. In the future I would like to validate these findings in more xenografts taken from several different HNSCC cell lines. Furthermore mice would be sacrificed at different treatment intervals allowing us to analyze how quickly the onset of decreased pEGFR occurs after cetuximab treatment. Based on these findings perhaps it would be possible to biopsy a patient's tumor at the start of their planned treatment when they would also receive cetuximab. Imaginably after a week of treatment these patients could be biopsied again in order to see if the level of pEGFR diminished. Ideally this could then show if further treatment with cetuximab is indicated.

Another attempt to predict cetuximab sensitivity could be based on the tumor level of EGF and cancer cell expression of EGFR. First this would have to be verified in a larger sample, possibly as a $3 \mathrm{D}$ co-culture with cancer associated fibroblasts. If a correlation would be found then future biopsies could be tested for EGF levels and cancer cells stained for EGFR expression using IHC. 


\section{ACKNOWLEDGEMENTS}

Karin Roberg, the best supervisor any $\mathrm{PhD}$-student could wish for, for being the one that introduced me to research, for always having time for me, for the endless patients displayed by you when I had to go to surgery. For your excellent help, guidance and dedication. For not doubting in my abilities, for your limitless support, and friendship. This thesis would never have happened without you. Thank you!

Ann-Charlotte Johansson, my co-supervisor that I upgraded to after my half time exam. What a lucky person I am to have gotten such a brilliant mind looking after me. Your input and re-writings of my papers has honestly been invaluable. Thank you for taking your time to explain to me the differences in opinions and theory that we have had. It was truly developing for me. Thank you for bringing a lot of energy into our lab. You truly are a spark!

Anna Ansell, my fellow co-author, PhD-student, and friend! I remember when you joined our group. You were small, shy and nervous. Of course you had to beat me by almost 1,5 years with your thesis. Am happy that you stayed close by to our/your former Roberg group. Its fun bumping into you in the corridors. Thank you for explaining to me that eating horses is a bad thing. But you are wrong about one thing; they are loads more dangerous then motorbikes.

Fredrik Jerhammar, my good friend and former $\mathrm{PhD}$ colleague. Thank you for rocking out with me to the amazing tunes that Abba made at various conferences! Imagine that we almost wrote a paper together! Have only one thing to say to you: Du e bäst!

Lovisa Farnebo, my dear friend, colleague and fellow researcher! Imagine that such a friendship can start by you throwing furniture at me $;$ Y You have always managed to make me laugh even in the darkest moments. Thank you for all the craziness that you bring into the picture such as dressing up as our digital projections in our matrix-lab-group pictures, for the numerous parties you have gotten us into. It is a real blast knowing you! 
Cathrine Nilsson, (1978-2010), post-doc. Am so happy I got the privilege to call you my close friend. Will always treasure your kindness. Often think of your brilliance, the amazing person and researcher you were. It was always very easy to be around you. I truly do miss You.

Linnea Sandin, for all the talks we have had and hopefully will have. Personal and some research. Imagine how life can quickly change, it's enough just to do some laboratory cell culture work $(;)$ I know I have become one close friend richer. Thank you for always giving me positive support.

My co-authors Linda Vainikka and Stina Garvin for excellent help and collaboration.

All of my colleagues on the $9^{\text {th }}$ floor at the department of Pathology, for being inviting, for discussions of great importance during coffee, for creating a brilliant atmosphere.

Marie, Göran, Linnea, Wilma, and Erik Andersson - Thank you for opening up to me during those hard times. Shared and learned some of lives hardest moments. Of course we shared tons of nice ones too. You all have a very special place in my life.

Maciej Tytor, my clinical supervisor, mentor, and close friend. You have given me so much; a brilliant clinical and surgical foundation, so much laughter during and after work, and also a lot of support. Thank you for everything.

All colleagues and friends at the ENT-department.

My parents Barbara and Andrzej Jedlinski, for the complete and utter support, no matter what. For always looking out for me. I almost never say it but I do love you both.

My children, Sture, Stella and Natalie, you have all changed my life for the better and it warms my heart to see how the three of you are so close. I know that you will be safe with each other in the future and that comforts me a lot. Thank you for providing a good distraction from the work during this thesis. 
Anna-Karin, the woman of my life. Thank you for showing me masses of support every day, not to mention during this last period during my thesis. You have taken such wonderful care of the children and me. Thank you for bringing meaning to my life. You do make me the luckiest man on earth. Simply put, I love You so much. 
References

64 


\section{REFERENCES}

Adida C, Crotty PL, McGrath J, Berrebi D, Diebold J \& Altieri DC (1998) Developmentally regulated expression of the novel cancer anti-apoptosis gene survivin in human and mouse differentiation. Am. J. Pathol. 152, 43-49.

Alsbeih G, El-Sebaie M, Al-Harbi N, Al-Buhairi M, Al-Hadyan K \& Al-Rajhi N (2007) Radiosensitivity of human fibroblasts is associated with amino acid substitution variants in susceptible genes and correlates with the number of risk alleles. Int. J. Radiat. Oncol. Biol. Phys. 68, 229-235.

Altieri DC (2008) New wirings in the survivin networks. Oncogene 27, 6276-6284.

Ang KK, Berkey BA, Tu X, Zhang H-Z, Katz R, Hammond EH, Fu KK \& Milas L (2002) Impact of epidermal growth factor receptor expression on survival and pattern of relapse in patients with advanced head and neck carcinoma. Cancer Res. 62, 7350-6.

Ansell A, Farnebo L, Grénman R, Roberg K \& Thunell LK (2009) Polymorphism of FGFR4 in cancer development and sensitivity to cisplatin and radiation in head and neck cancer. Oral Oncol. 45, 23-9.

Argiris A, Karamouzis MV, Raben D \& Ferris RL (2008) Head and neck cancer. Lancet 371, 1695-709.

Asiaf A, Ahmad ST, Mohammad SO \& Zargar MA (2014) Review of the current knowledge on the epidemiology, pathogenesis, and prevention of human papillomavirus infection. Eur. J. Cancer Prev. Off. J. Eur. Cancer Prev. Organ. ECP 23, 206-224.

Bange J, Prechtl D, Cheburkin Y, Specht K, Harbeck N, Schmitt M, Knyazeva T, Müller S, Gärtner S, Sures I, Wang H, Imyanitov E, Häring H-U, Knayzev P, Iacobelli S, Höfler $\mathrm{H} \&$ Ullrich A (2002) Cancer progression and tumor cell motility are associated with the FGFR4 $\operatorname{Arg}(388)$ allele. Cancer Res. 62, 840-847.

Bei R, Budillon A, Masuelli L, Cereda V, Vitolo D, Di Gennaro E, Ripavecchia V, Palumbo C, Ionna F, Losito S, Modesti A, Kraus MH \& Muraro R (2004) Frequent overexpression of multiple ErbB receptors by head and neck squamous cell carcinoma contrasts with rare antibody immunity in patients. J. Pathol. 204, 317-25.

Blobel CP (2005) ADAMs: key components in EGFR signalling and development. Nat. Rev. Mol. Cell Biol. 6, 32-43.

Blot WJ, McLaughlin JK, Winn DM, Austin DF, Greenberg RS, Preston-Martin S, Bernstein L, Schoenberg JB, Stemhagen A \& Fraumeni JF (1988) Smoking and drinking in relation to oral and pharyngeal cancer. Cancer Res. 48, 3282-3287.

Bokarewa M, Lindblad S, Bokarew D \& Tarkowski A (2005) Balance between survivin, a key member of the apoptosis inhibitor family, and its specific antibodies determines erosivity in rheumatoid arthritis. Arthritis Res. Ther. 7, R349-358. 
Bonner JA, Harari PM, Giralt J, Azarnia N, Shin DM, Cohen RB, Jones CU, Sur R, Raben D, Jassem J, Ove R, Kies MS, Baselga J, Youssoufian H, Amellal N, Rowinsky EK \& Ang KK (2006) Radiotherapy plus cetuximab for squamous-cell carcinoma of the head and neck. N. Engl. J. Med. 354, 567-78.

Bonner JA, Harari PM, Giralt J, Cohen RB, Jones CU, Sur RK, Raben D, Baselga J, Spencer SA, Zhu J, Youssoufian H, Rowinsky EK \& Ang KK (2010) Radiotherapy plus cetuximab for locoregionally advanced head and neck cancer: 5-year survival data from a phase 3 randomised trial, and relation between cetuximab-induced rash and survival. Lancet Oncol. 11, 21-28.

Boulikas T \& Vougiouka M (2003) Cisplatin and platinum drugs at the molecular level. (Review). Oncol. Rep. 10, 1663-1682.

Bullwinkel J, Baron-Lühr B, Lüdemann A, Wohlenberg C, Gerdes J \& Scholzen T (2006) Ki67 protein is associated with ribosomal RNA transcription in quiescent and proliferating cells. J. Cell. Physiol. 206, 624-635.

Burgess AW, Cho H-S, Eigenbrot C, Ferguson KM, Garrett TPJ, Leahy DJ, Lemmon MA, Sliwkowski MX, Ward CW \& Yokoyama S (2003) An open-and-shut case? Recent insights into the activation of EGF/ErbB receptors. Mol. Cell 12, 541-552.

Cantley LC (2002) The phosphoinositide 3-kinase pathway. Science 296, 1655-1657.

Chan G, Boyle JO, Yang EK, Zhang F, Sacks PG, Shah JP, Edelstein D, Soslow RA, Koki AT, Woerner BM, Masferrer JL \& Dannenberg AJ (1999) Cyclooxygenase-2 expression is up-regulated in squamous cell carcinoma of the head and neck. Cancer Res. 59, 991-994.

Chen C, Patel S, Corisdeo S, Liu X, Micolochick H, Xue J, Yang Q, Lei Y, Wang B \& Soltis D (2005) Generation and characterization of a panel of monoclonal antibodies specific for human fibroblast growth factor receptor 4 (FGFR4). Hybrid. 2005 24, 152-159.

Chen DJ \& Nirodi CS (2007) The epidermal growth factor receptor: a role in repair of radiation-induced DNA damage. Clin. Cancer Res. Off. J. Am. Assoc. Cancer Res. 13, 6555-6560.

Da Costa Andrade VC, Parise O, Hors CP, de Melo Martins PC, Silva AP \& Garicochea B (2007) The fibroblast growth factor receptor 4 (FGFR4) Arg388 allele correlates with survival in head and neck squamous cell carcinoma. Exp. Mol. Pathol. 82, 53-57.

Dallaglio K, Marconi A \& Pincelli C (2012) Survivin: a dual player in healthy and diseased skin. J. Invest. Dermatol. 132, 18-27.

Downward J, Parker P \& Waterfield MD (1984) Autophosphorylation sites on the epidermal growth factor receptor. Nature 311, 483-485.

D'Souza G, Kreimer AR, Viscidi R, Pawlita M, Fakhry C, Koch WM, Westra WH \& Gillison ML (2007) Case-control study of human papillomavirus and oropharyngeal cancer. $N$. Engl. J. Med. 356, 1944-1956. 
Dyson N, Howley PM, Münger K \& Harlow E (1989) The human papilloma virus-16 E7 oncoprotein is able to bind to the retinoblastoma gene product. Science 243, 934-937.

Ekblad L, Welinder C, Kjellén E, Brun E \& Wennerberg J (2014) Anti- or pro-proliferation Conditional options for TGF- $\alpha$ and cetuximab in head and neck squamous cell carcinoma. Oral Oncol.

Engelman JA, Luo J \& Cantley LC (2006) The evolution of phosphatidylinositol 3-kinases as regulators of growth and metabolism. Nat. Rev. Genet. 7, 606-619.

Estève P-O, Chin HG \& Pradhan S (2005) Human maintenance DNA (cytosine-5)methyltransferase and p53 modulate expression of p53-repressed promoters. Proc. Natl. Acad. Sci. U. S. A. 102, 1000-1005.

Farnebo L, Tiefenböck K, Ansell A, Thunell LK, Garvin S \& Roberg K (2013) Strong expression of survivin is associated with positive response to radiotherapy and improved overall survival in head and neck squamous cell carcinoma patients. Int. J. Cancer J. Int. Cancer 133, 1994-2003.

Fesik SW \& Shi Y (2001) Structural biology. Controlling the caspases. Science 294, 14771478

Fortugno P, Beltrami E, Plescia J, Fontana J, Pradhan D, Marchisio PC, Sessa WC \& Altieri DC (2003) Regulation of survivin function by Hsp90. Proc. Natl. Acad. Sci. U. S. A. $100,13791-13796$.

Francisco G, Menezes PR, Eluf-Neto J \& Chammas R (2008) XPC polymorphisms play a role in tissue-specific carcinogenesis: a meta-analysis. Eur. J. Hum. Genet. EJHG 16, $724-$ 734.

Friedberg EC (2001) How nucleotide excision repair protects against cancer. Nat. Rev. Cancer 1, 22-33.

Garrido C, Brunet M, Didelot C, Zermati Y, Schmitt E \& Kroemer G (2006) Heat shock proteins 27 and 70: anti-apoptotic proteins with tumorigenic properties. Cell Cycle Georget. Tex 5, 2592-2601.

Ghosh JC, Dohi T, Kang BH \& Altieri DC (2008) Hsp60 regulation of tumor cell apoptosis. J. Biol. Chem. 283, 5188-5194.

Giachino DF, Ghio P, Regazzoni S, Mandrile G, Novello S, Selvaggi G, Gregori D, DeMarchi M \& Scagliotti GV (2007) Prospective assessment of XPD Lys751Gln and XRCC1 Arg399Gln single nucleotide polymorphisms in lung cancer. Clin. Cancer Res. Off. J. Am. Assoc. Cancer Res. 13, 2876-2881.

Grandis JR \& Tweardy DJ (1993) Elevated levels of transforming growth factor alpha and epidermal growth factor receptor messenger RNA are early markers of carcinogenesis in head and neck cancer. Cancer Res. 53, 3579-84.

Grenman R, Burk D, Virolainen E, Buick RN, Church J, Schwartz DR \& Carey TE (1989) Clonogenic cell assay for anchorage-dependent squamous carcinoma cell lines using limiting dilution. Int. J. Cancer J. Int. Cancer 44, 131-6. 
Hager KM \& Gu W (2014) Understanding the non-canonical pathways involved in p53mediated tumor suppression. Carcinogenesis 35, 740-746.

Hatakeyama H, Cheng H, Wirth P, Counsell A, Marcrom SR, Wood CB, Pohlmann PR, Gilbert J, Murphy B, Yarbrough WG, Wheeler DL, Harari PM, Guo Y, Shyr Y, Slebos RJ \& Chung CH (2010) Regulation of heparin-binding EGF-like growth factor by miR-212 and acquired cetuximab-resistance in head and neck squamous cell carcinoma. PloS One 5, e12702.

Hawk ET, Viner JL, Dannenberg A \& DuBois RN (2002) COX-2 in cancer--a player that's defining the rules. J. Natl. Cancer Inst. 94, 545-546.

Hengstermann A, Linares LK, Ciechanover A, Whitaker NJ \& Scheffner M (2001) Complete switch from Mdm2 to human papillomavirus E6-mediated degradation of p53 in cervical cancer cells. Proc. Natl. Acad. Sci. U. S. A. 98, 1218-1223.

Horiot JC, Le Fur R, N'Guyen T, Chenal C, Schraub S, Alfonsi S, Gardani G, Van Den Bogaert W, Danczak S \& Bolla M (1992) Hyperfractionation versus conventional fractionation in oropharyngeal carcinoma: final analysis of a randomized trial of the EORTC cooperative group of radiotherapy. Radiother. Oncol. J. Eur. Soc. Ther. Radiol. Oncol. 25, 231-241.

Ishizawar R \& Parsons SJ (2004) c-Src and cooperating partners in human cancer. Cancer Cell 6, 209-214.

Jacobs B, De Roock W, Piessevaux H, Van Oirbeek R, Biesmans B, De Schutter J, Fieuws S, Vandesompele J, Peeters M, Van Laethem J-L, Humblet Y, Pénault-Llorca F, De Hertogh G, Laurent-Puig P, Van Cutsem E \& Tejpar S (2009) Amphiregulin and epiregulin mRNA expression in primary tumors predicts outcome in metastatic colorectal cancer treated with cetuximab. J. Clin. Oncol. Off. J. Am. Soc. Clin. Oncol. $27,5068-74$.

Jaramillo ML, Leon Z, Grothe S, Paul-Roc B, Abulrob A \& O'Connor McCourt M (2006) Effect of the anti-receptor ligand-blocking 225 monoclonal antibody on EGF receptor endocytosis and sorting. Exp. Cell Res. 312, 2778-2790.

Kelland L (2007) The resurgence of platinum-based cancer chemotherapy. Nat. Rev. Cancer 7, 573-584.

Khambata-Ford S, Garrett CR, Meropol NJ, Basik M, Harbison CT, Wu S, Wong TW, Huang $\mathrm{X}$, Takimoto $\mathrm{CH}$, Godwin AK, Tan BR, Krishnamurthi SS, Burris HA, Poplin EA, Hidalgo M, Baselga J, Clark EA \& Mauro DJ (2007) Expression of epiregulin and amphiregulin and K-ras mutation status predict disease control in metastatic colorectal cancer patients treated with cetuximab. J. Clin. Oncol. Off. J. Am. Soc. Clin. Oncol. $25,3230-7$.

Koki, Leahy \& Masferrer (1999) Potential utility of COX-2 inhibitors in chemoprevention and chemotherapy. Expert Opin. Investig. Drugs 8, 1623-1638.

Kubbutat MH, Jones SN \& Vousden KH (1997) Regulation of p53 stability by Mdm2. Nature 387, 299-303. 
Lammering G, Hewit TH, Holmes M, Valerie K, Hawkins W, Lin P-S, Mikkelsen RB \& Schmidt-Ullrich RK (2004) Inhibition of the type III epidermal growth factor receptor variant mutant receptor by dominant-negative EGFR-CD533 enhances malignant glioma cell radiosensitivity. Clin. Cancer Res. Off. J. Am. Assoc. Cancer Res. 10, 6732-43.

Lammering G, Valerie K, Lin P-S, Hewit TH \& Schmidt-Ullrich RK (2004) Radiationinduced activation of a common variant of EGFR confers enhanced radioresistance. Radiother. Oncol. J. Eur. Soc. Ther. Radiol. Oncol. 72, 267-73.

Laurent-Puig P, Lievre A \& Blons H (2009) Mutations and response to epidermal growth factor receptor inhibitors. Clin. Cancer Res. Off. J. Am. Assoc. Cancer Res. 15, $1133-$ 1139.

Lechler P, Balakrishnan S, Schaumburger J, Grässel S, Baier C, Grifka J, Straub RH \& Renkawitz T (2011) The oncofetal gene survivin is re-expressed in osteoarthritis and is required for chondrocyte proliferation in vitro. BMC Musculoskelet. Disord. 12, 150 .

Leemans CR, Braakhuis BJM \& Brakenhoff RH (2011) The molecular biology of head and neck cancer. Nat. Rev. Cancer 11, 9-22.

Leutenegger CM, Mislin CN, Sigrist B, Ehrengruber MU, Hofmann-Lehmann R \& Lutz H (1999) Quantitative real-time PCR for the measurement of feline cytokine mRNA. Vet. Immunol. Immunopathol. 71, 291-305.

Li C, Iida M, Dunn EF, Ghia AJ \& Wheeler DL (2009) Nuclear EGFR contributes to acquired resistance to cetuximab. Oncogene 28, 3801-3813.

Li S, Kussie P \& Ferguson KM (2008) Structural basis for EGF receptor inhibition by the therapeutic antibody IMC-11F8. Struct. Lond. Engl. 1993 16, 216-227.

Li S, Schmitz KR, Jeffrey PD, Wiltzius JJW, Kussie P \& Ferguson KM (2005) Structural basis for inhibition of the epidermal growth factor receptor by cetuximab. Cancer Cell 7, 301-11.

Liu T, Brouha B \& Grossman D (2004) Rapid induction of mitochondrial events and caspaseindependent apoptosis in Survivin-targeted melanoma cells. Oncogene 23, 39-48.

Liu X, Li P, Zhang S-T, You H, Jia J-D \& Yu Z-L (2008) COX-2 mRNA expression in esophageal squamous cell carcinoma (ESCC) and effect by NSAID. Dis. Esophagus Off. J. Int. Soc. Dis. Esophagus ISDE 21, 9-14.

Lowry O, Rosebrough N, Farr A \& J (1951) Protein measurement with the Folin phenol reagent. Chem 193 SRC - GoogleScholar, 265-75.

Luo J, Manning BD \& Cantley LC (2003) Targeting the PI3K-Akt pathway in human cancer: rationale and promise. Cancer Cell 4, 257-262.

Maa MC, Leu TH, McCarley DJ, Schatzman RC \& Parsons SJ (1995) Potentiation of epidermal growth factor receptor-mediated oncogenesis by c-Src: implications for the etiology of multiple human cancers. Proc. Natl. Acad. Sci. U. S. A. 92, 6981-6985. 
De Maio A (1999) Heat shock proteins: facts, thoughts, and dreams. Shock Augusta Ga 11, 112.

Mandal M, Myers JN, Lippman SM, Johnson FM, Williams MD, Rayala S, Ohshiro K, Rosenthal DI, Weber RS, Gallick GE \& El-Naggar AK (2008) Epithelial to mesenchymal transition in head and neck squamous carcinoma: association of Src activation with E-cadherin down-regulation, vimentin expression, and aggressive tumor features. Cancer 112, 2088-2100.

Mehra R, Cohen RB \& Burtness BA (2008) The role of cetuximab for the treatment of squamous cell carcinoma of the head and neck. Clin. Adv. Hematol. Oncol. HO 6, $742-750$.

Mita AC, Mita MM, Nawrocki ST \& Giles FJ (2008) Survivin: key regulator of mitosis and apoptosis and novel target for cancer therapeutics. Clin. Cancer Res. Off. J. Am. Assoc. Cancer Res. 14, 5000-5005.

Miyazaki T, Kato H, Faried A, Sohda M, Nakajima M, Fukai Y, Masuda N, Manda R, Fukuchi M, Ojima H, Tsukada K \& Kuwano H (2005) Predictors of response to chemo-radiotherapy and radiotherapy for esophageal squamous cell carcinoma. Anticancer Res. 25, 2749-2755.

Modjtahedi H, Styles J \& Dean C (1993) The growth-response of human tumor-cell lines expressing the EGF receptor to treatment with EGF and or mabs that block ligandbinding. Int. J. Oncol. 3, 237-43.

Morimoto Y, Ozaki T, Ouchida M, Umehara N, Ohata N, Yoshida A, Shimizu K \& Inoue H (2003) Single nucleotide polymorphism in fibroblast growth factor receptor 4 at codon 388 is associated with prognosis in high-grade soft tissue sarcoma. Cancer 98, 22452250 .

Muller PAJ \& Vousden KH (2013) p53 mutations in cancer. Nat. Cell Biol. 15, 2-8.

Münger K \& Howley PM (2002) Human papillomavirus immortalization and transformation functions. Virus Res. 89, 213-228.

Näsman A, Attner P, Hammarstedt L, Du J, Eriksson M, Giraud G, Ahrlund-Richter S, Marklund L, Romanitan M, Lindquist D, Ramqvist T, Lindholm J, Sparén P, Ye W, Dahlstrand H, Munck-Wikland E \& Dalianis T (2009) Incidence of human papillomavirus (HPV) positive tonsillar carcinoma in Stockholm, Sweden: an epidemic of viral-induced carcinoma? Int. J. Cancer J. Int. Cancer 125, 362-366.

O-charoenrat P, Modjtahedi H, Rhys-Evans P, Court WJ, Box GM \& Eccles SA (2000) Epidermal growth factor-like ligands differentially up-regulate matrix metalloproteinase 9 in head and neck squamous carcinoma cells. Cancer Res. 60, 1121-8.

Ohnishi K, Ota I, Takahashi A, Yane K, Matsumoto H \& Ohnishi T (2002) Transfection of mutant p53 gene depresses X-ray- or CDDP-induced apoptosis in a human squamous cell carcinoma of the head and neck. Apoptosis Int. J. Program. Cell Death 7, 367372 . 
Ondrey FG, Juhn SK \& Adams GL (1996) Inhibition of head and neck tumor cell growth with arachidonic acid metabolism inhibition. The Laryngoscope 106, 129-134.

Ongkeko WM, Altuna X, Weisman RA \& Wang-Rodriguez J (2005) Expression of protein tyrosine kinases in head and neck squamous cell carcinomas. Am. J. Clin. Pathol. 124, 71-6.

Panje WR (1981) Regression of head and neck carcinoma with a prostaglandin-synthesis inhibitor. Arch. Otolaryngol. Chic. Ill 1960 107, 658-663.

Pekkola-Heino K, Jaakkola M, Kulmala J \& Grénman R (1995) Comparison of cellular radiosensitivity between different localizations of head and neck squamous-cell carcinoma. J. Cancer Res. Clin. Oncol. 121, 452-6.

Peters LJ (2007) Changes in radiotherapeutic management of head and neck cancer: a 30-year perspective. Int. J. Radiat. Oncol. Biol. Phys. 69, S8-11.

Pignon JP, Bourhis J, Domenge C \& Designé L (2000) Chemotherapy added to locoregional treatment for head and neck squamous-cell carcinoma: three meta-analyses of updated individual data. MACH-NC Collaborative Group. Meta-Analysis of Chemotherapy on Head and Neck Cancer. Lancet 355, 949-955.

Poeta ML, Manola J, Goldwasser MA, Forastiere A, Benoit N, Califano JA, Ridge JA, Goodwin J, Kenady D, Saunders J, Westra W, Sidransky D \& Koch WM (2007) TP53 mutations and survival in squamous-cell carcinoma of the head and neck. N. Engl. J. Med. 357, 2552-2561.

Powers CJ, McLeskey SW \& Wellstein A (2000) Fibroblast growth factors, their receptors and signaling. Endocr. Relat. Cancer 7, 165-97.

Romano R, Palamaro L, Fusco A, Giardino G, Gallo V, Del Vecchio L \& Pignata C (2013) FOXN1: A Master Regulator Gene of Thymic Epithelial Development Program. Front. Immunol. 4, 187.

Rosenberg B, VanCamp L, Trosko JE \& Mansour VH (1969) Platinum compounds: a new class of potent antitumour agents. Nature 222, 385-386.

Saba NF, Choi M, Muller S, Shin HJC, Tighiouart M, Papadimitrakopoulou VA, El-Naggar AK, Khuri FR, Chen ZG \& Shin DM (2009) Role of cyclooxygenase-2 in tumor progression and survival of head and neck squamous cell carcinoma. Cancer Prev. Res. Phila. Pa 2, 823-829.

Sah NK, Khan Z, Khan GJ \& Bisen PS (2006) Structural, functional and therapeutic biology of survivin. Cancer Lett. 244, 164-171.

Saridaki Z, Tzardi M, Papadaki C, Sfakianaki M, Pega F, Kalikaki A, Tsakalaki E, Trypaki M, Messaritakis I, Stathopoulos E, Mavroudis D, Georgoulias V \& Souglakos J (2011) Impact of KRAS, BRAF, PIK3CA mutations, PTEN, AREG, EREG expression and skin rash in $\geq 2$ line cetuximab-based therapy of colorectal cancer patients. PloS One 6, e15980. 
Scaltriti M \& Baselga J (2006) The epidermal growth factor receptor pathway: a model for targeted therapy. Clin. Cancer Res. Off. J. Am. Assoc. Cancer Res. 12, 5268-5272.

Scioscia KA, Snyderman CH, Rueger R, Reddy J, D’Amico F, Comsa S \& Collins B (1997) Role of arachidonic acid metabolites in tumor growth inhibition by nonsteroidal antiinflammatory drugs. Am. J. Otolaryngol. 18, 1-8.

Sedaghat AR, Zhang Z, Begum S, Palermo R, Best S, Ulmer KM, Levine M, Zinreich E, Messing BP, Gold D, Wu AA, Niparko KJ, Kowalski J, Hirata RM, Saunders JR, Westra WH \& Pai SI (2009) Prognostic significance of human papillomavirus in oropharyngeal squamous cell carcinomas. The Laryngoscope 119, 1542-1549.

Shah JP (2007) Surgical approaches to the oral cavity primary and neck. Int. J. Radiat. Oncol. Biol. Phys. 69, S15-18.

Shin YK, Park JS, Kim HS, Jun HJ, Kim GE, Suh CO, Yun YS \& Pyo H (2005) Radiosensitivity enhancement by celecoxib, a cyclooxygenase (COX)-2 selective inhibitor, via COX-2-dependent cell cycle regulation on human cancer cells expressing differential COX-2 levels. Cancer Res. 65, 9501-9509.

Shirasuna K, Hayashido Y, Sugiyama M, Yoshioka H \& Matsuya T (1991) Immunohistochemical localization of epidermal growth factor (EGF) and EGF receptor in human oral mucosa and its malignancy. Virchows Arch. A Pathol. Anat. Histopathol. 418, 349-53.

Sigismund S, Woelk T, Puri C, Maspero E, Tacchetti C, Transidico P, Di Fiore PP \& Polo S (2005) Clathrin-independent endocytosis of ubiquitinated cargos. Proc. Natl. Acad. Sci. U. S. A. 102, 2760-2765.

Simpson DR, Mell LK \& Cohen EEW (2014) Targeting the PI3K/AKT/mTOR pathway in squamous cell carcinoma of the head and neck. Oral Oncol.

Sok JC, Coppelli FM, Thomas SM, Lango MN, Xi S, Hunt JL, Freilino ML, Graner MW, Wikstrand CJ, Bigner DD, Gooding WE, Furnari FB \& Grandis JR (2006) Mutant epidermal growth factor receptor (EGFRvIII) contributes to head and neck cancer growth and resistance to EGFR targeting. Clin. Cancer Res. Off. J. Am. Assoc. Cancer Res. 12, 5064-73.

Stransky N, Egloff AM, Tward AD, Kostic AD, Cibulskis K, Sivachenko A, Kryukov GV, Lawrence MS, Sougnez C, McKenna A, Shefler E, Ramos AH, Stojanov P, Carter SL, Voet D, Cortés ML, Auclair D, Berger MF, Saksena G, Guiducci C, Onofrio RC, Parkin M, Romkes M, Weissfeld JL, Seethala RR, Wang L, Rangel-Escareño C, Fernandez-Lopez JC, Hidalgo-Miranda A, Melendez-Zajgla J, Winckler W, Ardlie K, Gabriel SB, Meyerson M, Lander ES, Getz G, Golub TR, Garraway LA \& Grandis JR (2011) The mutational landscape of head and neck squamous cell carcinoma. Science 333, 1157-1160.

Strasser A, O’Connor L \& Dixit VM (2000) Apoptosis signaling. Annu. Rev. Biochem. 69, 217-245. 
Streit S, Bange J, Fichtner A, Ihrler S, Issing W \& Ullrich A (2004) Involvement of the FGFR4 Arg388 allele in head and neck squamous cell carcinoma. Int. J. Cancer J. Int. Cancer 111, 213-217.

Szentkúti G, Dános K, Brauswetter D, Kiszner G, Krenács T, Csákó L, Répássy G \& Tamás L (2014) Correlations Between Prognosis and Regional Biomarker Profiles in Head and Neck Squamous Cell Carcinomas. Pathol. Oncol. Res. POR.

Terakado N, Shintani S, Yano J, Chunnan L, Mihara M, Nakashiro K \& Hamakawa H (2004) Overexpression of cyclooxygenase-2 is associated with radioresistance in oral squamous cell carcinoma. Oral Oncol. 40, 383-389.

Thomas GR, Nadiminti H \& Regalado J (2005) Molecular predictors of clinical outcome in patients with head and neck squamous cell carcinoma. Int. J. Exp. Pathol. 86, 347363.

Tice DA, Biscardi JS, Nickles AL \& Parsons SJ (1999) Mechanism of biological synergy between cellular Src and epidermal growth factor receptor. Proc. Natl. Acad. Sci. U. S. A. 96, 1415-1420.

Vidal AE, Boiteux S, Hickson ID \& Radicella JP (2001) XRCC1 coordinates the initial and late stages of DNA abasic site repair through protein-protein interactions. EMBO J. $20,6530-6539$.

Vineis P, Alavanja M, Buffler P, Fontham E, Franceschi S, Gao YT, Gupta PC, Hackshaw A, Matos E, Samet J, Sitas F, Smith J, Stayner L, Straif K, Thun MJ, Wichmann HE, Wu AH, Zaridze D, Peto R \& Doll R (2004) Tobacco and cancer: recent epidemiological evidence. J. Natl. Cancer Inst. 96, 99-106.

Weber A, Hengge UR, Stricker I, Tischoff I, Markwart A, Anhalt K, Dietz A, Wittekind C \& Tannapfel A (2007) Protein microarrays for the detection of biomarkers in head and neck squamous cell carcinomas. Hum. Pathol. 38, 228-238.

Werness BA, Levine AJ \& Howley PM (1990) Association of human papillomavirus types 16 and 18 E6 proteins with p53. Science $248,76-79$.

Wheeler DL, Huang S, Kruser TJ, Nechrebecki MM, Armstrong EA, Benavente S, Gondi V, Hsu K-T \& Harari PM (2008) Mechanisms of acquired resistance to cetuximab: role of HER (ErbB) family members. Oncogene 27, 3944-3956.

Wheeler DL, Iida M, Kruser TJ, Nechrebecki MM, Dunn EF, Armstrong EA, Huang S \& Harari PM (2009) Epidermal growth factor receptor cooperates with Src family kinases in acquired resistance to cetuximab. Cancer Biol. Ther. 8, 696-703.

Wilson GD, Saunders MI, Dische S, Richman PI, Daley FM \& Bentzen SM (2001) bcl-2 expression in head and neck cancer: an enigmatic prognostic marker. Int. J. Radiat. Oncol. Biol. Phys. 49, 435-441.

Wilson KJ, Gilmore JL, Foley J, Lemmon MA \& Riese DJ (2009) Functional selectivity of EGF family peptide growth factors: implications for cancer. Pharmacol. Ther. 122, 18. 
Wirth LJ, Krane JF, Li Y, Othus M, Moran AE, Dorfman DM, Norris CM, Goguen L, Posner MR, Haddad RI \& Bertagnolli MM (2008) A pilot surrogate endpoint biomarker study of celecoxib in oral premalignant lesions. Cancer Prev. Res. Phila. Pa 1, 339-348.

Yoon YS \& Kim JC (2014) Recent applications of chemosensitivity tests for colorectal cancer treatment. World J. Gastroenterol. WJG 20, 16398-16408.

Zackrisson B, Nilsson P, Kjellén E, Johansson K-A, Modig H, Brun E, Nyman J, Friesland S, Reizenstein J, Sjödin H, Ekberg L, Lödén B, Mercke C, Fernberg J-O, Franzén L, Ask A, Persson E, Wickart-Johansson G, Lewin F, Wittgren L, Björ O \& Björk-Eriksson T (2011) Two-year results from a Swedish study on conventional versus accelerated radiotherapy in head and neck squamous cell carcinoma--the ARTSCAN study. Radiother. Oncol. J. Eur. Soc. Ther. Radiol. Oncol. 100, 41-48. 


\section{Papers}

The articles associated with this thesis have been removed for copyright reasons. For more details about these see:

http://urn.kb.se/resolve?urn=urn:nbn:se:liu:diva-113744 